\title{
Modifying effects of leaf litter extracts from invasive versus native tree species on copper-induced responses in Lemna minor
}

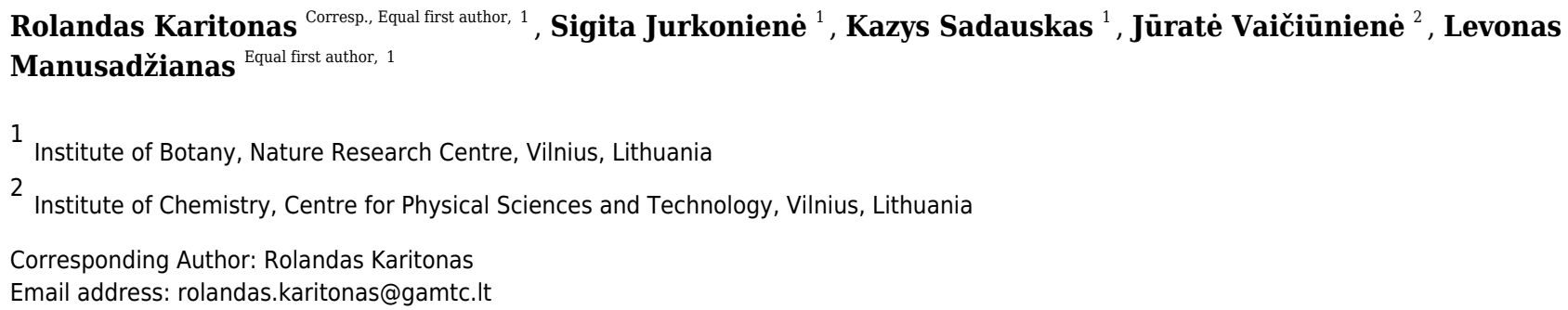

Invasive plant species tend to migrate from their native habitats under favourable climatic conditions; therefore, trophic and other relationships in ecosystems are changing. To investigate the effect of natural organic matter derived from native Alnus glutinosa tree species and from invasive in Lithuania Acer negundo tree species on copper toxicity in Lemna minor, we analysed the dynamics of $\mathrm{Cu}$ binding in aqueous leaf litter extracts (LLE) and plant accumulation, morphophysiological parameters, and antioxidative response. The results revealed that A.glutinosa LLE contained polyphenols ( $49 \mathrm{mg}$ pyrogallol acid equivalent (PAE)/g DM) and tannins (7.5 mg PAE/g DM), while A.negundo LLE contained only polyphenols (23 mg PAE/g DM). The ability of LLE to bind Cu increased rapidly over 1.5-3 $\mathrm{h}$ to $61 \%$ and $49 \%$ of the total Cu concentration ( $6.0 \pm 0.9 \mathrm{mg} / \mathrm{L})$, respectively for A.glutinosa ( $A G)$ and A.negundo (AN), then remained relatively stable until $48 \mathrm{~h}$. At the same time, L.minor accumulated 384, 241 or $188 \mu \mathrm{g} \mathrm{Cu/g} \mathrm{FW}$ when plants were exposed to $\mathrm{Cu}\left(100 \mu \mathrm{M} \mathrm{CuSO}_{4}\right)$, Cu with $100 \mathrm{mg} / \mathrm{L}$ dissolved organic carbon (DOC) from either AG LLE or AN LLE, accordingly. Catalase (CAT) and guaiacol peroxidase (POD) played a dominant role in hydrogen peroxide scavenging when plants were exposed to Cu and 10 or $100 \mathrm{mg} / \mathrm{L} \mathrm{DOC}_{\mathrm{AG}}$ mixtures in both the first (up to $6 \mathrm{~h}$ ) and the second (6-48 h) response phases. Due to functioning of oxidative stress enzymes, the levels of the lipid peroxidation product malondialdehyde (MDA) reduced in concentration-dependent manner, compared to $\mathrm{Cu}$ treatment. When combining $\mathrm{Cu}$ and $\mathrm{DOC}_{\mathrm{AN}}$ treatments, the most sensitive enzymes were POD, ascorbate peroxidase and glutathione reductase. Their activities collectively with CAT were sufficient to reduce MDA levels to $\mathrm{Cu}$-induced in the initial, but not the second response phase. These data suggest that leaf litter extracts of different phenolic compositions elicited different antioxidant response profiles resulting in different 
reductions of Cu stress, thus effecting L.minor frond and root development observed after seven days. The complex data from this study may be useful in modelling the response of the aquatic ecosystem to a changing environment. 
1 Modifying effects of leaf litter extracts from invasive versus native tree species on

2 copper-induced responses in Lemna minor

3 A running head title: Tree leaf litter DOM moderate Cu toxicity to L. minor

4 Rolandas Karitonas*, Sigita Jurkonienè, Kazys Sadauskas, Jūratė Vaičiūnienè ${ }^{1}$ and

5 Levonas Manusadžianas

6 Institute of Botany, Nature Research Centre, Vilnius, Lithuania

$7{ }^{1}$ Institute of Chemistry, Centre for Physical Sciences and Technology, Vilnius, Lithuania

8 *Corresponding author:

9 Rolandas Karitonas

10 E-mail: rolandas.karitonas@gamtc.lt

\begin{abstract}
Invasive plant species tend to migrate from their native habitats under favourable climatic conditions; therefore, trophic and other relationships in ecosystems are changing. To investigate the effect of natural organic matter derived from native Alnus glutinosa tree species and from invasive in Lithuania Acer negundo tree species on copper toxicity in Lemna minor, we analysed the dynamics of $\mathrm{Cu}$ binding in aqueous leaf litter extracts (LLE) and plant accumulation, morphophysiological parameters, and antioxidative response. The results revealed that $A$. glutinosa LLE contained polyphenols (49 $\mathrm{mg}$ pyrogallol acid equivalent (PAE)/g DM) and tannins (7.5 mg PAE/g DM), while $A$. negundo LLE contained only polyphenols (23 mg PAE/g DM). The ability of LLE to bind $\mathrm{Cu}$ increased rapidly over $1.5-3 \mathrm{~h}$ to $61 \%$ and $49 \%$ of the total $\mathrm{Cu}$ concentration $(6.0 \pm 0.9 \mathrm{mg} / \mathrm{L})$, respectively for A. glutinosa (AG) and $A$. negundo (AN), then remained relatively stable until $48 \mathrm{~h}$. At the same time, L. minor accumulated 384, 241 or $188 \mu \mathrm{g} \mathrm{Cu} / \mathrm{g}$ FW when plants were exposed to $\mathrm{Cu}\left(100 \mu \mathrm{M} \mathrm{CuSO}_{4}\right)$, Cu with $100 \mathrm{mg} / \mathrm{L}$ dissolved organic carbon (DOC) from either AG LLE or AN LLE, accordingly. Catalase (CAT) and guaiacol peroxidase (POD) played a dominant role in hydrogen peroxide scavenging when plants were exposed to $\mathrm{Cu}$ and 10 or $100 \mathrm{mg} / \mathrm{L}$ $\mathrm{DOC}_{\mathrm{AG}}$ mixtures in both the first (up to $6 \mathrm{~h}$ ) and the second (6-48 h) response phases. Due to functioning of oxidative stress enzymes, the levels of the lipid peroxidation product malondialdehyde (MDA) reduced in concentration-dependent manner, compared to $\mathrm{Cu}$ treatment. When combining $\mathrm{Cu}$ and $\mathrm{DOC}_{\mathrm{AN}}$ treatments, the most sensitive enzymes were POD, ascorbate peroxidase and glutathione reductase. Their activities collectively with CAT were sufficient to reduce MDA levels to $\mathrm{Cu}$-induced in the initial, but not the second response phase. These data suggest that leaf litter extracts of different phenolic compositions elicited different antioxidant response profiles resulting in different reductions of $\mathrm{Cu}$ stress, thus effecting $L$. minor frond and root development observed after seven days. The complex data from this study may be useful in modelling the response of the aquatic ecosystem to a changing environment.

Keywords: copper toxicity; invasive species; leaf litter extracts; Lemna minor; lipid peroxidation; oxidative stress enzymes.
\end{abstract}




\section{Introduction}

Copper is needed for normal plant growth and development and is a cofactor for physiological processes such as photosynthesis, mitochondrial respiration, superoxide scavenging, ethylene sensing and lignification (Maksymiec, 1997). However, copper released into the environment in surplus concentrations is toxic to plants (Naumann et al., 2007). Transition metals, including $\mathrm{Cu}$, stimulate the formation of hydroxyl radicals ( $\mathrm{OH}$ ) from the non-enzymatic chemical reaction between superoxide $\left(\mathrm{O}_{2}^{-}\right)$and $\mathrm{H}_{2} \mathrm{O}_{2}$ (HaberWeiss reaction). Excess $\mathrm{Cu}$ can induce negative effects including the production of reactive oxygen species (ROS) via Fenton reaction (Halliwell and Gutteridge, 1984). ROS, in turn, can oxidize lipids (De Vos et al., 1991), disrupt protein functions due to binding to sulphydryl groups (Weckx and Clijsters, 1996) and inhibit photosynthesis and electron transport (Thomas et al., 2013; Xia and Tian, 2009). Plant growth can be inhibited as a result.

The presence of oxygen in intracellular environments due to aerobic metabolism poses a constant oxidative threat to cellular structures and processes. ROS affect the metabolism, growth and development of plant cells. ROS formation and consumption are tiny balanced and coherent in cells. At any condition in which cellular redox homeostasis is disrupted, ROS production becomes far greater than the capacity of the tissues to scavenge them, thus can be defined as oxidative stress (Alscher et al., 1997). The environmental stressors can increase the synthesis of non-enzymatic antioxidants such as thiol tripeptides, glutathione and ascorbate and $\alpha$-tocopherol, as well as the modification of the activity of antioxidant enzymes including superoxide dismutase, catalase, glutathione peroxidase, ascorbate peroxidase and glutathione reductase (Foyer et al., 1997; Schützendübel and Polle, 2002). Accordingly, excess of $\mathrm{Cu}$ in plants can cause oxidative stress, and therefore change antioxidative pathways (Babu et al., 2003; De Vos et al., 1992; Gupta et al., 1999; Teisseire and Guy, 2000; Wang et al., 2004).

The solubility, adsorption, transport and toxicity of metals in natural surface waters are strongly influenced by complexation with dissolved organic matter (DOM) (Kim et al., 1999; Koukal et al., 2003; Manceau and Matynia, 2010; Marx and Heumann, 1999). Natural waters contain different concentrations of DOM, which, depending on the geographical area are ranging between $<1$ and $100 \mathrm{mgC} / \mathrm{L}$ (Wetzel, 2001). Higher DOM concentrations (up to $300 \mathrm{mgC} / \mathrm{L}$ ) have also been reported in some Canadian wetlands (Blodau et al., 2004). DOM is a complex and polymorphous mixture, which includes proteins, carbohydrates, polyphenols, and other vital compounds that originate chiefly from the degradation of plant and animal matter (Stevenson, 1994). A major fraction of DOM in waters comprises humic substances representing more than $60-80 \%$ of the total dissolved organic carbon (DOC), which consists mainly of humic and fulvic acids (Steinberg, 2003).

Leaf litter is a readily available allochthonous source of DOM and plays an important role in freshwater ecosystems serving as a key source of nutrients (Tank et al., 2010). The enrichment with DOM relates to litter quality, which, in turn, is leaf species-dependent and 
furthermore can depend whether they are of native or non-native origin (Casas et al., 2013). In addition, leaf litter emits phenolic compounds including tannins, a significant component of plant secondary metabolites (Lachman et al., 2011; Lin et al., 2006). Tannins may provide a nutrient conservation mechanism by reducing decomposition rates of litter and decreasing nitrogen leaching potential (Lin et al., 2010). It has been found that DOM might cause oxidative stress in freshwater organisms (Nimptsch and Pflugmacher, 2008; Steinberg et al., 2003), and leaf litter leachates obtained from various tree species such as white pine Pinus strobus and red oak Quercus robur (Earl et al., 2012) can be toxic to aquatic organisms. Moreover, it has been suggested that black alder Alnus glutinosa, native in Lithuania species, and boxelder maple Acer negundo, invasive in Lithuania species, impacted the same aquatic organisms in different ways (Krevš et al., 2013; Manusadžianas et al., 2014). A. negundo became widespread in Lithuania after its escape from cultivation in the mid-twentieth century (Gudžinskas, 1998). It colonized coastal zones of lakes and rivers that are dominated by autochthonous A. glutinosa (Prieditis, 1997). In this context, it might be interesting to reveal the potential of the DOM obtained from diverse species to modify metal effects on aquatic plants.

Alongside the natural sources, the increase of DOM in water bodies depends on rural and municipal activities. Similar anthropogenic sources of copper appearance were emphasized, i.e. agriculture and industrial wastes (Hou et al., 2007; Panagos et al., 2018), and combating massive growth of cyanobacteria (Huh and Ahn, 2017). To investigate possible phytotoxicity effects, we used duckweed Lemna minor, a well-known bioindicator of eutrophic water bodies (Environment Canada, 2007; US Environmental Protection Agency, 2012). This plant is considered to be a suitable model for physiological and ecotoxicological studies due to its small size, fast growth rate, vegetative reproduction, ease of culture and sensitivity to numerous pollutants. Lemna has been used for antioxidative response studies (Forni et al., 2012; Radić and Pevalek-Kozlina, 2010; Razinger et al., 2007; Teisseire et al., 1998; Teisseire and Guy, 2000; Zezulka et al., 2013). However, information on the involvement of oxidative stress under the combined treatment of $\mathrm{Cu}$ and DOM obtained from leaf litter extracts is lacking in L. minor.

The main objective of this study was to investigate the effect of natural organic matter derived from native Alnus glutinosa tree species and from invasive in Lithuania Acer negundo tree species on copper toxicity in L. minor. We focused on time-dependent alterations of (1) Cu binding to DOM in media and accumulation in the plant, (2) morphophysiological parameters (frond area and root length), and (3) oxidative stress characteristics such as lipid peroxidation, hydrogen peroxide content and the activities of antioxidant enzymes, i.e. catalase, guaiacol and ascorbate peroxidases, and glutathione reductase. We limited our observations of oxidative stress characteristics to 48 hours; thus, relatively high concentrations of $100 \mu \mathrm{M} \mathrm{CuSO}_{4}$ and up to $100 \mathrm{mg} / \mathrm{L}$ DOC were used. 
119

120

121

122

123

124

125

126

127

128

129

130

131

132

133

134

135

136

137

138

139

140

141

142

143

144

145

146

147

148

149

150

151

152

153

154

155

\section{Materials and Methods}

Plant material

We have been collecting duckweed (Lemna minor L.) plants from a local freshwater pond

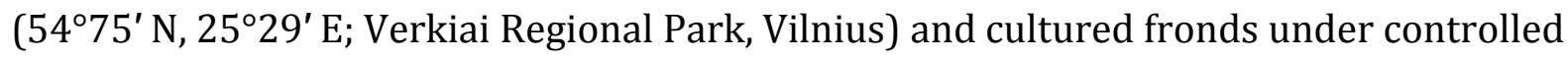
conditions for several years. Species specificity of experimental clone morphologically similar to L. minor was proved by sequencing the chloroplast DNA fragment (611 bp) at the Laboratory of Molecular Ecology of the Nature Research Centre (Vilnius). The highest chloroplast DNA sequence identity (99\%) to L. minor strain RDSC 7210 (Sequence ID KX212888.1), which included ATPase subunit I gene, partial cds; atpF-atpH intergenic spacer, complete sequence; and ATPase subunit II gene, partial cds, indicated that plant clones used for the experiments in the current study should be attributed to L. minor species.

A stock culture was cultivated in 500-mL plastic containers $60 \times 85 \times 100(\mathrm{~mm}, \mathrm{WxLxH})$ in a modified Steinberg growth medium containing $3.46 \mathrm{mM} \mathrm{KNO}_{3}, 1.25 \mathrm{mM} \mathrm{Ca}\left(\mathrm{NO}_{3}\right)_{2}, 0.66$ $\mathrm{mM} \mathrm{KH}_{2} \mathrm{PO}_{4}, 0.072 \mathrm{mM} \mathrm{K}_{2} \mathrm{HPO}_{4}, 0.41 \mathrm{mM} \mathrm{MgSO}_{4}, 0.63 \mu \mathrm{M} \mathrm{ZnSO}_{4}, 1.94 \mu \mathrm{M} \mathrm{H}_{3} \mathrm{BO}_{3}{ }^{*}, 0.18 \mu \mathrm{M}$ $\mathrm{Na}_{2} \mathrm{MoO}^{*}, 0.91 \mu \mathrm{M} \mathrm{MnCl}_{2}{ }^{*}, 2.81 \mu \mathrm{M} \mathrm{FeCl}_{3}{ }^{*}$ and $4.03 \mu \mathrm{M} \mathrm{Na}_{2} \mathrm{EDTA}^{* *}$ (chemicals were from Roth, Acros Organics ${ }^{*}$ and Fisher ${ }^{* *}$ ). The pH was adjusted to 6.0 with $1 \mathrm{M} \mathrm{NaOH}$.

Stock cultures and treated plants were kept in growth chambers at $24 \pm 2{ }^{\circ} \mathrm{C}$ under constant illumination with cool white fluorescent light at a photosynthetic photon flux density of $160 \mu \mathrm{mol} \mathrm{m}{ }^{-2} \mathrm{~s}^{-1}$.

Preparation of aqueous extracts

Fallen leaves of $A$. negundo and A. glutinosa were collected in Rudnia (54 $05^{\prime} \mathrm{N}, 24^{\circ} 40^{\prime} \mathrm{E}$; Varèna district, Lithuania) in autumn. After collection, tree leaves were dried for 10 days in the shade at room temperature. The dried materials (without petiole and central vein) were mechanically ground to obtain a homogenous powder. One gram powder was extracted in $100 \mathrm{~mL}$ of deionised water $\left(\mathrm{dH}_{2} \mathrm{O}\right)$ for $3 \mathrm{~h}$ at $65^{\circ} \mathrm{C}$ followed by rapid filtration through a Whatman \#3 disk in order to obtain a clear crude extract solution, and then refiltered through a nitro-cellulose paper filter $(0.2 \mu \mathrm{m})$ to reduce the risk of interference by microorganisms.

\section{Experimental design}

The experimental scheme comprised control (growth medium) and four treatments (growth medium supplemented with $\mathrm{Cu}\left(100 \mu \mathrm{M} \mathrm{CuSO}_{4}\right.$ or $\left.6.4 \mathrm{mg} \mathrm{Cu} / \mathrm{L}\right) ; 100 \mathrm{mg} / \mathrm{L} \mathrm{DOC}$; $\mathrm{Cu}+10 \mathrm{mg} / \mathrm{L} \mathrm{DOC}$ and $\mathrm{Cu}+100 \mathrm{mg} / \mathrm{L}$ DOC. Plants were incubated in 500-mL plastic containers $(60 \times 85 \times 100)$ having $200 \mathrm{~mL}$ of the corresponding medium. Media were adjusted to $\mathrm{pH} 6$.

For growth experiments, healthy colonies with 2-3 fronds from stock cultures were transferred to the containers with the corresponding exposure medium. The frond area 
156 (zones without the signs of chlorosis) and root length were measured at 0-day and after

157

158

159

160

161

162

163

164

165

166

167

168

169

170

171

172

173

174

175

176

177

178

179

180

181

182

183

184

185

186

187

188

189

190

191

192

193

194

seven days by using image control system (Software MOTIC 2.0). The growth rate per day was calculated with the following equation $r=\left(\ln _{\mathrm{t} 2}-\ln x_{\mathrm{t} 1}\right) / t_{2}-t_{1}$, where $\mathrm{x}_{\mathrm{t} 1}$ and $\mathrm{x}_{\mathrm{t} 2}$ are the values of observation parameter at $t_{1}$ and $t_{2}$ day, respectively. Two independent experiments in quadruplicate were conducted.

To study $\mathrm{H}_{2} \mathrm{O}_{2}$ kinetics, lipid peroxidation and antioxidant enzyme activities, the cultures were started by transferring healthy colonies with 3-4 fronds from stock cultures into four containers (0.8-0.9 $\mathrm{g}$ in each container) for each corresponding exposure medium. Plant samples were collected $0.75,1.5,3,6,12,24$ and $48 \mathrm{~h}$ after the onset of the exposure. For each exposure time, we prepared new exposure medium. Two independent experiments in quadruplicate for each parameter at each exposure time were conducted. Then samples of L. minor ( $0.2 \mathrm{~g}$ each) were processed after Hildebrand et al. (1986). Cold potassium phosphate buffer $(0.1 \mathrm{M}, \mathrm{pH} 7.0)$ containing $1 \%(\mathrm{w}: \mathrm{v})$ polyvinylpyrrolidone and $1 \%(\mathrm{v}: \mathrm{v})$ Triton X-100 was added to chilled $\left(4^{\circ} \mathrm{C}\right)$ mortar and pestle containing the sample. Each sample was macerated with $1 \mathrm{~mL}$ of extracting buffer and was further grounded with another $1 \mathrm{~mL}$ of the buffer. A $1.5 \mathrm{~mL}$ aliquot of homogenate was centrifuged at $15000 \mathrm{~g}$ for $15 \mathrm{~min}$ at $4^{\circ} \mathrm{C}$ (Hou et al., 2007). The supernatant was frozen immediately for future total protein content and enzyme assays. Total protein content was determined using bovine serum albumin (BSA) as standard (Bradford, 1976). Spectrophotometric measurements were carried out on a Libra S32 PC UV-VIS (Biochrom, UK).

Chemicals used for the determination of the total protein content and oxidative enzyme activities were purchased from Sigma-Aldrich (ascorbic acid, BSA, $\mathrm{Na}_{2}$ EDTA, FolinCiocalteau's phenol reagent, hide powder, $\mathrm{H}_{2} \mathrm{O}_{2}$, pyrogallol, polyvinylpyrrolidone, sodium carbonate decahydrate, Triton X-100, thiobarbituric acid (TBA), trichloroacetic acid (TCA)) and from Roth (GSSG, $\mathrm{KH}_{2} \mathrm{PO}_{4}, \mathrm{~K}_{2} \mathrm{HPO}_{4}, \mathrm{NADPH}, \mathrm{TRIS}$ ).

\section{Determination of $\mathrm{Cu}$}

Before determining the metal content, the plants from control and $\mathrm{Cu}, \mathrm{Cu}+10 \mathrm{mg} / \mathrm{L} \mathrm{DOC}$ and $\mathrm{Cu}+100 \mathrm{mg} / \mathrm{L} \mathrm{DOC}$ treatments (2 experiments with four replicates at each exposure time) were washed triple with deionised water. All liquids on the surface of plant materials were blotted with paper towels. $0.2 \mathrm{~g}$ of fresh weight of plant materials was transferred to a ceramic crucible (Haldenwanger, Waldkraiburg, Germany) to destroy the combustible (organic) portion of the sample by thermal decomposition in a muffle furnace (SNOL$1,6.2,5$, Borispol, Ukraine) at $450-550^{\circ} \mathrm{C}$ for $2-3 \mathrm{~h}$. After the sample was digested in $0.5 \mathrm{~mL}$ pure $\mathrm{HNO}_{3}$ (Roth, Karlsruhe, Germany) and heated until the acid evaporates up to a half volume and made up to final volume of $5 \mathrm{~mL}$ with $\mathrm{dH}_{2} \mathrm{O}$.

$\mathrm{Cu}$ fractionation in treatment solutions (without plants) followed Adam et al. (2014) procedure. The fraction with dissolved $\mathrm{Cu}$ was obtained after ultrafiltration for $1 \mathrm{~h}$ in Microsep $^{\mathrm{TM}}$ Advance Centrifugal Devices (Pall Corporation, Ann Arbor, MI, USA) containing polyethersulfone membranes with a cut-off of $1 \mathrm{kDa}$, at $5000 \mathrm{~g}$ (5430R, Eppendorf,

Peer) reviewing PDF | (2019:12:44535:1:1:CHECK 8 May 2020) 
195

196

197

198

199

200

201

202

203

204

205

206

207

208

209

210

211

212

213

214

215

216

217

218

219

220

221

222

223

224

225

226

227

228

229

230

Hamburg, Germany). Cu content was determined in duplicate at $0.75,1.5,3,6,12,24$ and $48 \mathrm{~h}$ before and after ultrafiltration by Perkin Elmer Optima 7000 Dual View ICP Optical Emission Spectrometer (Waltham, MA, USA) with standard method and calculated according to the standard curve. $\mathrm{Cu}$ concentration was expressed as $\mathrm{mg} / \mathrm{L} \mathrm{or} \mu \mathrm{g} / \mathrm{g}$ fresh weight (FW).

$$
\mathrm{CuSO}_{4} \bullet 5 \mathrm{H}_{2} \mathrm{O} \text { was from Sigma-Aldrich (purum p.a.). }
$$

\section{Catalase (CAT) EC1.11.1.6}

CAT was determined according to Aebi (1984). The assay medium contained $50 \mathrm{mM}$

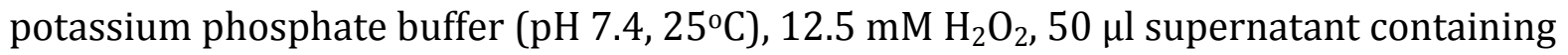
enzyme extract and $\mathrm{dH}_{2} \mathrm{O}$ to make up the volume to $3 \mathrm{~mL}$. The reaction was initiated by adding $\mathrm{H}_{2} \mathrm{O}_{2}$. The decrease in absorbance of $\mathrm{H}_{2} \mathrm{O}_{2}$ was recorded at $240 \mathrm{~nm}$ for $60 \mathrm{~s}$ with $50 \mathrm{mM}$ potassium phosphate buffer used as the blank. The enzyme activity was calculated from the initial rate of the reaction using extinction coefficient $\varepsilon=0.04 \mathrm{mM}^{-1} \mathrm{~cm}^{-1}$ for $\mathrm{H}_{2} \mathrm{O}_{2}$.

\section{Ascorbate peroxidase (APX) EC 1.11.1.11}

APX activity was measured according to the method described by Nakano and Asada (1981). The $3 \mathrm{~mL}$ reaction medium was composed of $50 \mathrm{mM}$ potassium phosphate buffer

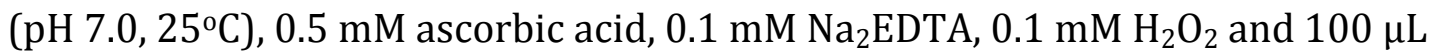
supernatant containing enzyme extract. The reaction was initiated by adding $\mathrm{H}_{2} \mathrm{O}_{2}$. The decrease in the optical density to ascorbic acid was recorded at $290 \mathrm{~nm}$ for $30 \mathrm{~s}$. The enzyme activity was calculated from the initial rate of the reaction using $\varepsilon=2.8 \mathrm{mM}^{-1} \mathrm{~cm}^{-1}$ for ascorbate.

\section{Guaiacol peroxidase (POD) EC 1.11.1.7}

POD activity was determined according to Upadhyaya et al. (1985). The assay medium contained $2.5 \mathrm{~mL}$ of $50 \mathrm{mM}$ potassium phosphate buffer $\left(\mathrm{pH} 6.1,25^{\circ} \mathrm{C}\right), 1 \mathrm{~mL} 1 \% \mathrm{H}_{2} \mathrm{O}_{2}$, $1 \mathrm{~mL} 1 \%$ guaiacol and $50 \mu \mathrm{L}$ supernatant containing enzyme extract. The reaction was initiated by adding supernatant containing enzyme extract. The change in the optical density was recorded at $420 \mathrm{~nm}$ for $1 \mathrm{~min}$. The enzyme activity was calculated using $\varepsilon=26.6 \mathrm{mM}^{-1} \mathrm{~cm}^{-1}$ for oxidized tetraguaiacol polymer.

Glutathione reductase (GR) EC 1.6.4.2

GR activity was determined according to Mannervik (2001). The assay medium contained $0.2 \mathrm{M}$ potassium phosphate buffer ( $\mathrm{pH}$ 7.0)/2 mM Na${ }_{2}$ EDTA, $20 \mathrm{mM} \mathrm{GSSG}, 2 \mathrm{mM}$ NADPH and $100 \mu \mathrm{L}$ supernatant containing enzyme extract and $\mathrm{dH}_{2} \mathrm{O}$ to make up the volume to $1 \mathrm{~mL}$. The reaction mixture was equilibrated at $30^{\circ} \mathrm{C}$. The decrease in the NADPH concentration was recorded at $340 \mathrm{~nm}$ for $1 \mathrm{~min}$ against the assay solution. Corrections were made for the non-enzymatic oxidation of NADPH by recording the decrease at $340 \mathrm{~nm}$ 
231 without adding GSSG to the assay medium. The enzyme activity was calculated from the 232 initial rate of the reaction after subtracting the non-enzymatic oxidation using $\varepsilon=6.2 \mathrm{mM}^{-}$ $233{ }^{1} \mathrm{~cm}^{-1}$ for NADPH.

234

235

236

237

238

239

240

241

242

243

244

\section{Determination of hydrogen peroxide}

The level of $\mathrm{H}_{2} \mathrm{O}_{2}$ in plant was determined according to Jana and Choudhuri (1981) with slight modification (Chen et al., 2000). $\mathrm{H}_{2} \mathrm{O}_{2}$ was extracted by homogenizing $0.2 \mathrm{~g}$ plant with $2 \mathrm{ml}$ of phosphate buffer $(50 \mathrm{mM}, \mathrm{pH} 7.0)$. The homogenate was centrifuged at $6000 \mathrm{~g}$ for $25 \mathrm{~min}$ at $4^{\circ} \mathrm{C} .900 \mu \mathrm{L}$ of the supernatant was mixed with $300 \mu \mathrm{L}$ of $0.1 \%$ titanium chloride in $20 \%(\mathrm{v} / \mathrm{v})_{2} \mathrm{H}_{2} \mathrm{SO}_{4}$ and mixture was then centrifuged at $6000 \mathrm{~g}$ for $15 \mathrm{~min}$. The intensity of yellow colour of the supernatant was measured at $410 \mathrm{~nm} . \mathrm{H}_{2} \mathrm{O}_{2}$ level was calculated using the extinction coefficient $0.28 \mu \mathrm{mol}^{-1} \mathrm{~cm}^{-1}$.

\section{Determination of lipid peroxidation}

The level of lipid peroxidation in plant was assessed by thiobarbituric acid (TBA) reactive metabolites chiefly malondialdehyde (MDA) as described by Heath and Packer (1968). Plant tissues $(0.2 \mathrm{~g}$ ) were extracted in $2 \mathrm{~mL}$ of $0.25 \%$ TBA made in $10 \%$ TCA. Extract was heated at $95^{\circ} \mathrm{C}$ for $30 \mathrm{~min}$ and then quickly cooled on ice. After centrifugation at $10000 \mathrm{~g}$ for $10 \mathrm{~min}$, the absorbance of the supernatant was measured at $532 \mathrm{~nm}$. Correction of nonspecific turbidity was made by subtracting the absorbance value taken at $600 \mathrm{~nm}$. The level of lipid peroxidation was expressed as MDA concentration formed using $\varepsilon=155 \mathrm{mM}^{-1} \mathrm{~cm}^{-1}$.

\section{Total phenol and tannin contents}

The total phenol content of the dry leaves was measured spectrophotometrically after reaction with Folin-Ciocalteau phenol reagent, according to the manual method described by Singleton et al. (1968) with little modifications (Amorim et al., 2008; Atanassova et al., 2011). A $1 \mathrm{~mL}$ aliquot of extracts or a standard solution of pyrogallol acid was added to a $25 \mathrm{~mL}$ volumetric flask containing $9 \mathrm{~mL}$ of $\mathrm{dH}_{2} \mathrm{O} .1 \mathrm{~mL}$ of the Folin-Ciocalteau phenol reagent was added to the mixture and shaken. After $5 \mathrm{~min}, 10 \mathrm{~mL}$ of $7 \% \mathrm{Na}_{2} \mathrm{CO}_{3}$ solution was added to the mixture. The solution was diluted to $25 \mathrm{~mL}$ with $\mathrm{dH}_{2} \mathrm{O}$ and incubated for $30 \mathrm{~min}$ at room temperature. Absorbance was measured at $760 \mathrm{~nm}$ against a blank prepared with $\mathrm{dH}_{2} \mathrm{O}$.

For determination of tannin content, aqueous extracts of leaves were shaken with hide powder for $60 \mathrm{~min}$ in ultrasonic bath. The non-tannin phenolics in the clear supernatant were determined in the way similar to this of total phenol content. Tannin content was calculated as a difference between total phenolic and non-tannin phenolic contents in the extract. Pyrogallol acid in deionised water was used for making a standard curve. Total phenol and tannin values are expressed as pyrogallol acid equivalents (PAE) in $\mathrm{mg} / \mathrm{g} \mathrm{DM}$. 
267

268

269

270

271

272

273

274

275

276

277

278

279

280

281

282

283

284

285

286

287

288

289

290

291

292

293

294

295

296

297

298

299

300

301

302

Dissolved organic carbon

DOC concentration in DOM extracts was determined according to ISO 8245:1999 in a certified analytical laboratory (JSC Water Investigations, Vilnius, Lithuania). Dissolved organic carbon in DOM extracts was determined according to ISO 15705 in a certified analytical laboratory (JSC Water Investigations, Vilnius, Lithuania).

\section{Statistical analysis}

The statistical analysis was carried out using the software PASW Statistics 18.0 (Predictive Analytics Software, IBM).

To validate an aggregation of the replicates from two experiments on frond and root growth rates, the two-way MANOVA were used. The factors in the analysis were a two-level experiment factor (experiment 1 and experiment 2) and a seven-level treatment factor. To validate an aggregation of the replicates from two experiments on specific enzyme activity, MDA or $\mathrm{H}_{2} \mathrm{O}_{2}$ concentrations, the two-way ANOVA were used. The factors in the analysis were a two-level experiment factor (experiment 1 and experiment 2) and a five-level treatment factor. In both analyses, there was no significant difference between two levels of experiment factor and interaction between the factors ( $p>0.05)$, therefore, the replicates were pooled to yield $n=8$.

After checking for normality (the Shapiro-Wilk test) and homogeneity of variances (the Levene test) the differences of treatments from control within each leaf species were analysed by the one-way ANOVA and the Dunnet test $(\alpha=0.05)$. Additionally, the Tukey post-hoc test was used for differences among treatments $(\alpha=0.05)$.

\section{Results}

Frond and root growth rate

The duckweed frond and root growth rates (FGR and RGR, respectively) were significantly affected by all treatments, with an exception of FGR in the treatment with $100 \mathrm{mg} / \mathrm{L} \mathrm{DOC}$

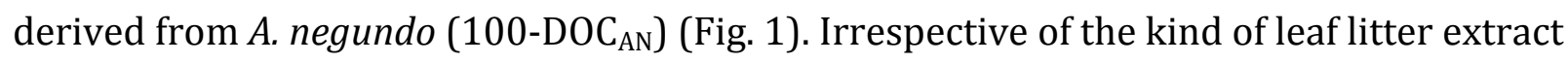
(LLE) and the type of treatment, the reduction in root length was higher than in the frond area.

As for the effect on fronds, $\mathrm{Cu}(100 \mu \mathrm{M}$ or $6.4 \mathrm{mg} / \mathrm{L})$ slowed the development of frond area by $97 \%$ after seven-day exposure (Fig. 1A). Due to the development of chlorosis and thus the decrease of a photosynthetically active square, the FGR was negative $\left(-0.3 \mathrm{~mm}^{2} \mathrm{~d}^{-}\right.$ 1 ). The $100-\mathrm{DOC}_{\mathrm{AN}}$ diminished insignificantly the development of the frond area. Due to chlorosis, the FGR was $-0.02 \mathrm{~mm}^{2} \mathrm{~d}^{-1}$ in $\mathrm{Cu}+10-\mathrm{DOC}_{\mathrm{AG}}$ treatment, and 5.0 times lower than the controls in $\mathrm{Cu}+100-\mathrm{DOC}_{\mathrm{AG}}$. The mixtures of $\mathrm{Cu}$ with $A$. negundo LLE of 10 and $100 \mathrm{mg} / \mathrm{L}$ DOC both stopped the growth of fronds. 
303

304

305

306

307

308

309

310

311

312

313

314

315

316

317

318

319

320

321

322

323

324

325

326

327

328

329

330

331

332

333

334

335

336

337

338

339

340

As for the effect on roots, the growth was not observed over seven days in L. minor treated by $\mathrm{Cu}$ (Fig. 1B). $100 \mathrm{mg} / \mathrm{L}$ DOC derived from A. glutinosa (100-DOC $\mathrm{AG}$ ) significantly diminished the development of roots (root growth rate (RGR) decreased 2.1 times compared to controls). The $100-\mathrm{DOC}_{\mathrm{AN}}$ significantly decreased the RGR by 1.6 times. The mixture of $\mathrm{Cu}+10-\mathrm{DOC}_{\mathrm{AG}}$ inhibited growth of the roots totally, while the effect of $\mathrm{Cu}+100$ DOC $_{\mathrm{AG}}$ was lower (RGR decreased 5.1 times compared to controls). The mixtures of $\mathrm{Cu}$ with A. negundo LLE of 10 and $100 \mathrm{mg} / \mathrm{L}$ DOC both diminished RGR by 8.8 and 2.1 times compared to controls, respectively.

Fig. 1. Frond (A) and root (B) growth rates of L. minor in control (C) and exposed for seven days with $100 \mu \mathrm{M} \mathrm{CuSO}_{4}(\mathrm{Cu})$, mixtures of $\mathrm{Cu}$ and $A$. glutinosa leaf litter extracts (LLE) of 10 and $100 \mathrm{mg} / \mathrm{L} \mathrm{DOC}\left(\mathrm{Cu}+10-\mathrm{DOC}_{\mathrm{AG}}\right.$ and $\left.\mathrm{Cu}+100-\mathrm{DOC}_{\mathrm{AG}}\right)$, mixtures of $\mathrm{Cu}$ and $A$. negundo LLE of 10 and $100 \mathrm{mg} / \mathrm{L} \mathrm{DOC}\left(\mathrm{Cu}+10-\mathrm{DOC}_{\mathrm{AN}}\right.$ and $\left.\mathrm{Cu}+100-\mathrm{DOC}_{\mathrm{AN}}\right)$ as well as with $100 \mathrm{mg} / \mathrm{L}$ DOC of $A$. glutinosa (100-DOC ${ }_{\mathrm{AG}}$ ) and A. negundo (100-DOC $\mathrm{AN}_{\mathrm{AN}}$ LLE. Data represent mean $\pm S D(n=8)$. Asterisks indicate significant difference from the control, different letters indicate significant difference among the means $(\alpha=0.05)$.

\section{Total phenols and tannins}

Polyphenol and tannin concentrations in the DOM of A. glutinosa leaf litter were quite high (49 and $7.5 \mathrm{mg}$ PAE/g DM, respectively), meanwhile DOM of $A$. negundo leaf litter had as much as twice lower polyphenol concentration (23 mg PAE/g DM) and no tannins.

\section{Cu accumulation}

The ability of LLE to bind $\mathrm{Cu}$ increased rapidly. Lower concentrations of dissolved $\mathrm{Cu}$ measured after ultrafiltration in the mixtures of $\mathrm{Cu}+100-\mathrm{DOC}_{\mathrm{AG}}$ and $\mathrm{Cu}+100-\mathrm{DOC}_{\mathrm{AN}}$, made up $61.9 \%$ and $63.8 \%$, respectively, of the total $\mathrm{Cu}(6.0 \pm 0.9 \mathrm{mg} / \mathrm{L}, \mathrm{n}=26)$ already after 45 min.

Lower concentrations of dissolved $\mathrm{Cu}$ were measured (after ultrafiltration) in the mixtures of $\mathrm{Cu}+100-\mathrm{DOC}_{\mathrm{AG}}$ and $\mathrm{Cu}+100-\mathrm{DOC}_{\mathrm{AN}}$ already after $45 \mathrm{~min}$, making up $61.9 \%$ and 63.8\% of the total $\mathrm{Cu}(6.0 \pm 0.9 \mathrm{mg} / \mathrm{L}, \mathrm{n}=26)$, respectively. The percent of dissolved Cu decreased further until $1.5 \mathrm{~h}$ in the case of $100-\mathrm{DOC}_{\mathrm{AG}}$ and then remained relatively stable $(39.3 \%$ of the total $\mathrm{Cu}$ ) up to the end of exposure at $48 \mathrm{~h}$, while it diminished until $3 \mathrm{~h}$ in the case of $100-\mathrm{DOC}_{\mathrm{AN}}$ and then remained relatively stable up to the end of exposure $(51.4 \%$ of the total $\mathrm{Cu}$ ).

The $\mathrm{Cu}$ concentration in L. minor increased with time in all treatments (Fig. 2). The plant accumulated $99.6 \pm 4.6$ and $384 \pm 20.4 \mu \mathrm{g} \mathrm{Cu} / \mathrm{g} \mathrm{FW}$ in the treatment with $\mathrm{Cu}$, respectively at $45 \mathrm{~min}$ and $48 \mathrm{~h}$. Similar $\mathrm{Cu}$ uptake was found in plants treated with $\mathrm{Cu}+10-\mathrm{DOC}_{\mathrm{AG}}$ or $\mathrm{Cu}+10-\mathrm{DOC}_{\mathrm{AN}}$. However, $100 \mathrm{mg} / \mathrm{L} \mathrm{DOC}$ obtained from each of the leaf extracts diminished $\mathrm{Cu}$ uptake compared to $\mathrm{Cu}$-treatment throughout all the exposure 
341

342

343

344

345

346

347

348

349

350

351

352

353

354

355

356

357

358

359

360

361

362

363

364

365

366

367

368

369

370

371

372

373

374

375

376

377

periods (Fig. 2). Accumulated $\mathrm{Cu}$ content was $55.6 \pm 2.7$ and $241 \pm 6.1 \mu \mathrm{g} \mathrm{Cu} / \mathrm{g} \mathrm{FW}$, respectively at $45 \mathrm{~min}$ and $48 \mathrm{~h}$ for $A$. glutinosa, and $60.8 \pm 4.0$ and $188 \pm 7.8 \mu \mathrm{g} \mathrm{Cu} / \mathrm{g} \mathrm{FW}$, respectively at $45 \mathrm{~min}$ and $48 \mathrm{~h}$ for $A$. negundo treatments.

Fig.2. $\mathrm{Cu}$ concentration in L. minor treated by $\mathrm{Cu}$ and $\mathrm{Cu}+\mathrm{DOC}$ of leaf litter extracts ( $\mu \mathrm{g} \mathrm{g}^{-}$ $\left.{ }^{1} \mathrm{FW}\right)$. Plants were incubated in control medium (घ), $100 \mu \mathrm{M} \mathrm{Cu}(\bullet), 100 \mu \mathrm{M} \mathrm{Cu}+10 \mathrm{mg} / \mathrm{L}$ DOC ( $\nabla), 100 \mu \mathrm{M} \mathrm{Cu}+100 \mathrm{mg} / \mathrm{L}$ DOC ( $\mathbf{\Delta})$ from A. glutinosa or A. negundo. Each value represents mean $\pm S D(n=8)$. Asterisks indicate significant difference from the control at $\alpha$ $=0.05$.

\section{Hydrogen peroxide}

The highest changes in hydrogen peroxide levels in plants were induced at early stages of the treatments. The $\mathrm{H}_{2} \mathrm{O}_{2}$ content increased significantly after $3 \mathrm{~h}$ of exposure to $\mathrm{Cu}$, its combinations with either A. glutinosa or A. negundo extracts, and to $100-\mathrm{DOC}_{\mathrm{AG}}$ or $100-$ $\mathrm{DOC}_{\mathrm{AN}}$ alone (Fig. 3). At this exposure time, it was approximately by 2.2 times higher in $\mathrm{Cu}$, $\mathrm{Cu}+10-\mathrm{DOC}_{\mathrm{AG}}, \mathrm{Cu}+100-\mathrm{DOC}_{\mathrm{AG}}$ and $100-\mathrm{DOC}_{\mathrm{AG}}$ treatments than in control $0.27 \pm 0.10 \mathrm{mM}, \mathrm{n}$ =56), and there were no significant differences among these treatments. However, treatments that included $A$. negundo extracts induced DOC-dependent $\mathrm{H}_{2} \mathrm{O}_{2}$ levels in L. minor. The $\mathrm{H}_{2} \mathrm{O}_{2}$ levels in $\mathrm{Cu}+10-\mathrm{DOC}_{\mathrm{AN}}$ and $\mathrm{Cu}+100-\mathrm{DOC}_{\mathrm{AN}}$ treatments exceeded that of $\mathrm{Cu}$ treatment by $21 \%$ and $30 \%$, respectively, and reached maximum $40 \%$ value in the treatment of $100 \mathrm{mg} / \mathrm{L} \mathrm{DOC}$ AN.

At $12 \mathrm{~h}$ exposure, irrespective to the kind of leaf extract, the level of hydrogen peroxide in the treatments of $\mathrm{Cu}$ and its combinations with the extracts did not exceed that of control, but it was by $60 \%$ higher in the treatments of the leaf extracts alone (Fig. 3). Subsequently, within the 24-48 h exposure period, the level of $\mathrm{H}_{2} \mathrm{O}_{2}$ in L. minor treated with $100-\mathrm{DOC}_{\mathrm{AG}}$ or $100-\mathrm{DOC}_{\mathrm{AN}}$ decreased to that of control, whereas $\mathrm{Cu}$ and its combinations with leaf extracts induced augmentation of hydrogen peroxide up to 1.5-1.7 times.

Fig. 3. Concentration of $\mathrm{H}_{2} \mathrm{O}_{2}$ in L. minor treated by $\mathrm{Cu}$, DOC or combinations of $\mathrm{Cu}$ and DOC of corresponding leaf litter extracts. Plants were incubated in control medium ( $\square), 100 \mu \mathrm{M}$ $\mathrm{Cu}(\bullet), 100 \mathrm{mg} / \mathrm{L}$ DOC from A. glutinosa or A. negundo (o), and Cu $+10 \mathrm{mg} / \mathrm{L} \mathrm{DOC} \mathrm{( \nabla )} \mathrm{or}$ $\mathrm{Cu}+100 \mathrm{mg} / \mathrm{L} \mathrm{DOC}(\boldsymbol{\Delta})$. Each value represents mean $\pm \mathrm{SD}(\mathrm{n}=8)$. Asterisks indicate significant difference from the control at $\alpha=0.05$. 


\section{Lipid peroxidation}

After $1.5 \mathrm{~h}$ of exposure, a significant increase of MDA concentration in L. minor over the control levels (Fig. 4, $10.1 \pm 2.13 \mathrm{nM} / \mathrm{g} \mathrm{FW}$ and $9.58 \pm 2.22 \mathrm{nM} / \mathrm{g} \mathrm{FW}$, left and right graphs, respectively) was observed in all treatments, and irrespective to the leaf species (Fig. 4). This 20-45\% increase in MDA content was led by its decrease that continued up to 3-6 h. Then, MDA augmentation was observed up to $48 \mathrm{~h}$ in the treatments with $\mathrm{Cu}$ and the mixtures of $\mathrm{Cu}$ and the extracts of both leaf species, however in different strength. Specifically, in the case of A.glutinosa, the addition of $100 \mathrm{mg} / \mathrm{L}$ DOC suppressed Cuinduced augmentation of MDA more strongly than the addition of $10 \mathrm{mg} / \mathrm{L} \mathrm{DOC} \mathrm{(Fig.} \mathrm{4).} \mathrm{At}$ $48 \mathrm{~h}$, no significant difference in MDA was observed between $\mathrm{Cu}$ and the combined treatment of $\mathrm{Cu}+10-\mathrm{DOC}_{\mathrm{AG}}$. Contrary, in the case of $A$. negundo, the addition of neither 10 nor $100 \mathrm{mg} / \mathrm{L}$ DOC were able to change significantly the course of Cu-induced augmentation of MDA (Fig. 4), the level of which, after $48 \mathrm{~h}$, reached as almost twice higher as the control level.

After the initial approximately 20\%-peak in MDA content at $1.5 \mathrm{~h}$, the effect of $100 \mathrm{mg} / \mathrm{L}$ DOC extracts obtained from the NOM of both leaf species was weak, especially in the case of $A$.glutinosa, and showed no more than $15 \%$ deviation from the control level of MDA in exposures longer than six hours (Fig. 4).

Fig. 4. Lipid peroxidation expressed as MDA concentration in L. minor treated by $\mathrm{Cu}, \mathrm{DOC}$ or combinations of $\mathrm{Cu}$ and DOC from A. glutinosa or A. negundo leaf litter extracts. Plants were incubated in control medium ( $\bullet$ ), $100 \mu \mathrm{M} \mathrm{Cu}(\bullet), 100 \mathrm{mg} / \mathrm{L} \mathrm{DOC} \mathrm{(o),} \mathrm{and}$ $\mathrm{Cu}+10 \mathrm{mg} / \mathrm{L} \mathrm{DOC}(\boldsymbol{\nabla})$ or $\mathrm{Cu}+100 \mathrm{mg} / \mathrm{L}$ DOC $(\boldsymbol{\Delta})$. Each value represents mean $\pm \mathrm{SD}(\mathrm{n}=$ 8). Asterisks indicate significant difference from the control at $\alpha=0.05$.

\section{CAT activity}

After 45 min exposure of L. minor plants, significant increases of CAT activities were observed in the treatments of $\mathrm{Cu}+100-\mathrm{DOC}_{\mathrm{AG}}, \mathrm{Cu}+100-\mathrm{DOC}_{\mathrm{AN}}$ and 100-DOC $\mathrm{AN}$ (Fig. 5). After $1.5 \mathrm{~h}$, the plants responded by significant increases of CAT activities to $\mathrm{Cu}$, $\mathrm{Cu}+10-\mathrm{DOC}_{\mathrm{AG}}$ and $\mathrm{Cu}+100-\mathrm{DOC}_{\mathrm{AG}}$ treatments in case of $A$. glutinosa, while the reaction in case of $A$. negundo was weaker. Then, after the initial increases in CAT activity, the reaction, in general, slowed down towards the control level (682 $\pm 188 \mathrm{nkat} / \mathrm{mg}$ protein and $800 \pm 121 \mathrm{nkat} / \mathrm{mg}$ protein for treatments of $A$. glutinosa and $A$. negundo, respectively; mean $\pm S D, n=56$ ) from $3^{\text {rd }}$ hour and up to the end of exposure at $48 \mathrm{~h}$, with irregular deviations. The exceptions comprised the decreasing tendency in CAT activities in the treatments of $100 \mathrm{mg} / \mathrm{L}$ DOC of both leaf species and with $\mathrm{Cu}+100-\mathrm{DOC}_{\mathrm{AN}}$ reaching significantly lower levels from those of controls by $20-30 \%$ at the end of exposure as well as the increasing tendency in CAT activities in the treatment of $\mathrm{Cu}+10-\mathrm{DOC}_{\mathrm{AG}}$ reaching significantly higher level from the controls by $20 \%$ at the end of exposure (Fig. 5). 
416

417

418

419

420

421

422

423

424

425

426

427

428

429

430

431

432

433

434

435

436

437

438

439

440

441

442

443

444

445

446

447

448

449

450

451

452

453

454

\section{POD activity}

Guaiacol peroxidase activities were significantly enhanced after treatments of $\mathrm{Cu}$ and its mixture with 10 and $100 \mathrm{mg} / \mathrm{L}$ DOC from A. glutinosa, but not with the $100-\mathrm{DOC}_{\mathrm{AG}}$, during the $45 \mathrm{~min}-48 \mathrm{~h}$ period reaching a $2-2.5$-fold increase at 24 and $48 \mathrm{~h}$ (Fig. 5). In case of A. negundo, the increases of POD activity over control (316 \pm 122 nkat/mg protein and $406 \pm 112 \mathrm{nkat} / \mathrm{mg}$ protein for treatments of $A$. glutinosa and $A$. negundo, respectively; mean $\pm S D, n=56$ ) were significant later, throughout the $12-48 \mathrm{~h}$ period, in the same treatments as above, and again with the exception of $100-\mathrm{DOC}_{\mathrm{AN}}$ (Fig. 5).

Fig. 5. Activities of catalase (CAT), guaiacol peroxidase (POD), ascorbate peroxidase (APX) and glutathione reductase (GR) in L. minor treated by $\mathrm{Cu}$, DOC of leaf litter extracts from A. glutinosa or $A$. negundo, and combinations of $\mathrm{Cu}$ and the DOC of respective extracts. Plants were incubated in control medium (-), $100 \mu \mathrm{M} \mathrm{Cu}(\bullet), 100 \mathrm{mg} / \mathrm{L} \mathrm{DOC} \mathrm{(o),}$ $\mathrm{Cu}+10 \mathrm{mg} / \mathrm{L} \mathrm{DOC}(\boldsymbol{\nabla})$ or $\mathrm{Cu}+100 \mathrm{mg} / \mathrm{L}$ DOC $(\boldsymbol{\Delta})$. Each value represents mean $\pm \mathrm{SD}(\mathrm{n}=$ 8). Asterisks indicate significant difference from the control at $\alpha=0.05$.

\section{APX activity}

No ascorbate peroxidase activity alterations were observed at $45^{\text {th }} \mathrm{min}$, meanwhile, at $1.5 \mathrm{~h}$, the $15-20 \%$ decreases were evident in the treatments of $\mathrm{Cu}+10-\mathrm{DOC}_{\mathrm{AG}}$ and $\mathrm{Cu}+100-\mathrm{DOC}_{\mathrm{AG}}$, and $\mathrm{Cu}+10-\mathrm{DOC}_{\mathrm{AN}}$ (Fig. 5). Then, at the 6-24 h period, the significant suppression of APX activities was observed in the treatments of $\mathrm{Cu}, \mathrm{Cu}+10-\mathrm{DOC}_{\mathrm{AG}}$ and $\mathrm{Cu}+100-\mathrm{DOC}_{\mathrm{AG}}$, and at $6^{\text {th }}$ hour, in the treatment of $\mathrm{Cu}+10-\mathrm{DOC}_{\mathrm{AN}}$ (Fig. 5). At the end of exposure at 48-h, the activities of all treatments did not differ from those of controls $(32.6 \pm 6.99 \mathrm{nkat} / \mathrm{mg}$ protein and $15.2 \pm 2.47 \mathrm{nkat} / \mathrm{mg}$ protein for treatments of $A$. glutinosa and $A$. negundo, respectively; mean $\pm \mathrm{SD}, \mathrm{n}=56$ ).

\section{GR activity}

The glutathione reductase activity changes in L. minor were irregular during the 12 hours of exposure in all treatments with the DOM of A. glutinosa and $\mathrm{Cu}$ alone, then GR activity decreased by approximately $20 \%$ below control level (409 \pm 46.6 nkat/mg protein and $430 \pm 72.6 \mathrm{nkat} / \mathrm{mg}$ protein for treatments of $A$. glutinosa and $A$. negundo, respectively; mean $\pm S D, n=56$ ) in the treatments of $\mathrm{Cu}$ and $\mathrm{Cu}+10-\mathrm{DOC}_{\mathrm{AG}}$ (Fig. 5). At 24 and $48 \mathrm{~h}, \mathrm{GR}$ activity increased up to approximately $20 \%$ in the treatment of $\mathrm{Cu}+100-\mathrm{DOC}_{\mathrm{AG}}$. In the case of $A$. negundo, the activity of GR activity was slightly, yet significantly, suppressed in the treatments of $\mathrm{Cu}+10-\mathrm{DOC}_{\mathrm{AN}}$ and $\mathrm{Cu}+100-\mathrm{DOC}_{\mathrm{AN}}$, during the $1.5-3-\mathrm{h}$ period. Then GR activity tended to recover to the control level at $24 \mathrm{~h}$ and to exceed it at the end of $48 \mathrm{~h}$ exposure period, in the treatment of $\mathrm{Cu}+10-\mathrm{DOC}_{\mathrm{AN}}$, while a significant increase in $20-30 \%$ above control level was seen in the treatment of $\mathrm{Cu}+100-\mathrm{DOC}_{\mathrm{AN}}$ during the period of $12-$ $48 \mathrm{~h}$ (Fig. 5). No significant alterations of GR activities were found in the LLE of $100 \mathrm{mg} / \mathrm{L}$ DOC of either species. 


\section{Discussion}

457

458

459

460

461

462

463

464

465

466

467

468

469

470

471

472

473

474

475

476

477

478

479

480

481

482

483

484

485

486

487

488

489

490

491

492

493

Our results showed a high accumulation of copper in L. minor, which increased with time over $48 \mathrm{~h}$. Similar accumulation properties of duckweed for this metal have already been documented for various exposure durations (Drost et al., 2007; Kanoun-Boulé et al., 2009; Razinger et al., 2007). The accumulation of metals in aquatic plants is often accompanied by a variety of morphological and physiological changes, some of which directly contribute to the tolerance capacity of plants (Prasad et al., 2001; Xing et al., 2010). L. minor exposed to $\mathrm{Cu}$, the extracts from A. glutinosa or $A$. negundo leaf litter, and to the combination of $\mathrm{Cu}$ with the extracts indicated inhibition of the growth parameters, enhanced levels of the lipid peroxidation and altered enzyme activities. To explore oxidative damage, we applied certainly toxic concentration of $\mathrm{Cu}(100 \mu \mathrm{M})$ within up to 48-hour exposure durations as compared to growth inhibition values of 7-d EC50, i.e. 2.7 and $9.7 \mu \mathrm{M}$ reported by Nauman et al. (2007) and Drost et al.(2007), respectively. The time span longer than about one day can already be considered as long-term since the amount of L. minor biomass doubles every two days (Environment Canada, 2007) and the doubling time for fronds ranges from 1.3 to 2.8 days (Wang, 1990) under optimal nutrient, light and temperature conditions. According to our findings, the reduction in root growth rate was higher than in the frond growth rate, irrespective of the kind of treatment. It is known that root length inhibition is a more sensitive endpoint than that of the frond area (Gopalapillai et al., 2014). However, the concentration-dependent antagonistic action of $\mathrm{Cu}$ and $A$. glutinosa extract mixture was evident on fronds and roots, while in the case of $\mathrm{Cu}$ and $A$. negundo extract mixture this was evident on roots only, suggesting that the origins of the diminishing influence of A. glutinosa and A. negundo extracts on $\mathrm{Cu}$-induced toxicity effects should not be the same.

The complex interactions between physical-chemical and biological factors in the aquatic medium may change metal bioavailability (Cuss and Guéguen, 2012; Koukal et al., 2003). The data obtained in Cu measurements in L. minor within $45 \mathrm{~min}-48 \mathrm{~h}$ period revealed that the accumulation rate in the combined treatments of $\mathrm{Cu}$ and A. glutinosa or A. negundo leaf extracts (100 mg/L DOC) was respectively two or three times lower than that in the $\mathrm{CuSO}_{4}$ treatment $\left(\sim 6 \mu \mathrm{g} \mathrm{g}^{-1} \mathrm{FW} \mathrm{h}^{-1}\right)$. The $\mathrm{Cu}$ accumulation dynamics at a constant rate did not correspond with the free $\mathrm{Cu}$ ions concentration dynamics in media, wherein it reached relatively constant level after $1.5 \mathrm{~h}$ or $3 \mathrm{~h}$, respectively for mixtures of $\mathrm{Cu}$ and A. glutinosa or $A$. negundo leaf extracts, and the $\mathrm{Cu}^{2+}$ levels were respectively $39 \%$ and $51 \%$ of that of nominal $\mathrm{Cu}$ concentration. Fact that $\mathrm{Cu}^{2+}$ concentration in the medium with NOM from $A$. negundo leaves remained higher than that from A. glutinosa, but a higher amount of $\mathrm{Cu}$ accumulated in L. minor in the case of NOM from A. glutinosa leaves suggests that part of $\mathrm{Cu}$ could enter the cell being bound on NOM or could be bound in the cell wall, and this part was higher in the case of $A$. glutinosa leaf extract. This assumption is supported by the comparative analysis of effects on L. minor root growth rate (RGR). As large as twice the 
494 increase of inhibition of $R G R\left(=\left(R G R_{C u+100-D O C}-R_{G R} R_{100-D O C}\right) / R R_{100-D O C}\right)$ was found for the

495

496

497

498

499

500

501

502

503

504

505

506

507

508

509

510

511

512

513

514

515

516

517

518

519

520

521

522

523

524

525

526

527

528

529

530

531

532 mixture of $\mathrm{Cu}$ and $A$. glutinosa leaf extract as for $\mathrm{Cu}$ and $A$. negundo (Fig. 1). Otherwise, a stronger effect on L. minor exposed to the mixture of $\mathrm{Cu}$ and $A$. negundo leaf extract should be observed; at least, due to a higher concentration of $\mathrm{Cu}$ ions measured in the medium. The mechanisms of copper ions translocation from the medium into plant cell comprise, at least, transition metal transporters (González-Guerrero et al., 2016; Palmgren and Nissen, 2011) including low-molecular-weight organic molecules (Sinclair and Krämer, 2012) and binding in the cell wall. It was estimated that $74 \%$ of $\mathrm{Cu}$ accumulated in the cell wall of macrophytic alga Nitellopsis obtusa, when its internodal cells were treated with $50 \mu \mathrm{M}$ of $\mathrm{CuSO}_{4}$ (Manusadžianas et al., 2017).

Plants exposed to long-term stress pass through different physiological states, from resistant to exhaustive (Lichtenthaler, 1996); thus, different kinetics of primary and successive plant responses might be expected. We found two phases of responses: namely, the first (up to $6 \mathrm{~h}$ ) and the second one (within 6-48 h) could be identified for lipid peroxidation and hydrogen peroxide, and also, in part, enzyme activity kinetics. In addition, frond abscission/disintegration delimitated these response phases at the physiological level. A process of chlorosis to necrosis leading to frond disintegration is a recognized symptom of toxicity in fronds of Lemna exposed to pollutants (Khellaf and Zerdaoui, 2009). Release of daughter fronds from the metal stressed mother frond would increase the chance of the daughter fronds survival (Li and Xiong, 2004).

The high content of $\mathrm{Cu}(100 \mu \mathrm{gCu} / \mathrm{g} \mathrm{FW})$ accumulated in L. minor over initial 45 minutes caused a half-fold increase in the amount of MDA at $1.5 \mathrm{~h}$ and temporal increase of $\mathrm{H}_{2} \mathrm{O}_{2}$ with the peak at $3 \mathrm{~h}$. It is widely accepted that malondialdehyde, the end product of lipid peroxidation, can be used as an indicator of membrane damage (Heath and Packer, 1968) and oxidative stress (Zezulka et al., 2013). At the end of the first response phase (plant resistance state), we observed the frond abscission. The oxidative stress progressed during the second response phase (plant exhaustive state) in terms of up to a 2-fold increase in MDA content and elevated $\mathrm{H}_{2} \mathrm{O}_{2}$ over control level at $48 \mathrm{~h}$. A similar picture, in general, could be seen when plants were exposed to $\mathrm{Cu}$ and its combinations with leaf litter extracts; however, in the case of $\mathrm{Cu}$ and $A$. glutinosa leaf extract mixture, MDA content in L. minor was inversely dependent on DOC concentration in the extract (Fig.4).

The response patterns of the plants exposed to each of the leaf litter extracts singly were mainly the same as exposed to $\mathrm{Cu}$ or $\mathrm{Cu}$ combined with the extracts, during the first response phase (up to $6 \mathrm{~h}$ ). However, the levels of $\mathrm{H}_{2} \mathrm{O}_{2}$ and MDA relaxed to that of control during the second response phase. Therefore, it can be suggested that plants treated with extracts alone underwent oxidative stress in terms of $\mathrm{H}_{2} \mathrm{O}_{2}$ production and MDA increase, however, due to enzymatic activity they were able to resist this initial stress and consequently avoid detrimental effects in terms of growth and development at the final 7-day exposure, yet partially slowed down (Figs. 1, 3 and 4). 
533

534

535

536

537

538

539

540

541

542

543

544

545

546

547

548

549

550

551

552

553

554

555

556

557

558

559

560

561

562

563

564

565

566

567

568

569

570

571

572

In the first response phase, alterations of oxidative stress enzymes in L. minor were observed as early as after 45-min, the shortest exposure period. Specifically, $\mathrm{Cu}$ or its combinations with $A$. glutinosa extracts induced CAT activity increases that were not led by significant overrun of the control levels of $\mathrm{H}_{2} \mathrm{O}_{2}$ and MDA. This should show that the initial response of the enzymes prevented membrane damage due to ROS generation. Later on, however, concentrations of $\mathrm{H}_{2} \mathrm{O}_{2}$ and MDA significantly increased over the control reaching their peak values within 1.5-3 h, and this coincided with the maximum CAT activity. Bayliak et al. (2006) and Martins and English (2014) have demonstrated that increasing $\mathrm{H}_{2} \mathrm{O}_{2}$ levels (up to $1 \mathrm{mM}$ ) in yeast cells stimulate CAT. We measured $\mathrm{H}_{2} \mathrm{O}_{2}$ concentrations of 0.6-0.7 $\mathrm{mM}$ to be the highest ones in treated L. minor. Similar fast mobilization of CAT was considered as a cellular adaptation in primary leaves of Phaseolus vulgaris to cope with $\mathrm{H}_{2} \mathrm{O}_{2}$ overproduction generated by $\mathrm{Cu}^{2+}$ (Weckx and Clijsters, 1996). Interestingly, the increase in CAT activity during the initial $1.5 \mathrm{~h}$ was followed by attenuation of APX activity (Fig. 5). This might be linked with the decreased GR activity since GR converts GSSH into GSH by consuming NADPH and so maintains AsA level. One of the characteristic properties of APX that distinguishes it from POD, cytochrome c peroxidase and GR, is the rapid inactivation of the enzyme under conditions where an electron donor is absent (Miyake and Asada, 1996). The lower reduction state of AsA could be due to both the insufficient supply of electrons from GSH via direct interaction between GSH and AsA, and inadequate activities of MDHAR and DHAR (Asada and Takahashi, 1987; Foyer and Halliwell, 1976). In our experiments, GR activity began to increase after the initial decrease at $45 \mathrm{~min}$, restoring the control level after three hours of exposure to $\mathrm{Cu}$ and $\mathrm{Cu}+\mathrm{DOC}_{\mathrm{AG}}$ (Fig. 5). This increase of GR activity created, indirectly, favourable conditions for augmentation of ascorbic acid content, which allowed the APX activity to increase toward the control level during 1.5-3 h. Results of Xiang and Oliver (1998) have shown that the liquid culture of Arabidopsis tissues exposed to $100 \mu \mathrm{M} \mathrm{Cu}^{2+}$ respond fairly rapidly by increasing the transcript levels of the genes encoding the GSH-synthesizing enzymes (GSH1, GSH2) and the GSSG-reducing enzyme (GR1). Elevated transcript levels were evident one hour after the exposure to $\mathrm{Cu}^{2+}$, plateaued at six hours, and remained high for $18 \mathrm{~h}$, and the high levels of transcripts continued for a few days under this condition. Another factor that prevented $\mathrm{H}_{2} \mathrm{O}_{2}$ accumulation in L. minor treated by $\mathrm{Cu}$ and $\mathrm{Cu}+\mathrm{DOC}_{\mathrm{AG}}$ could be elevated POD activity within a 3-6-h period, which compensated gradual decrease of CAT activity toward the control level (Fig. 5). Similar concomitant activation of POD and inactivation of CAT has been found in various plants as an oxidative stress response to pathogen within 30 hours (Madhusudhan et al., 2009).

The observed alterations in enzyme activities are likely related to oxidative reactions due to increased $\mathrm{H}_{2} \mathrm{O}_{2}$ level, which may eventually yield increased lipid peroxidation. Indeed, at the end of the first response phase, the highest MDA content in L. minor was found in the treatment with $\mathrm{Cu}$ (Fig. 2), which, however, was diminished by the $\mathrm{DOC}_{\mathrm{AG}}$, but not by the $\mathrm{DOC}_{\mathrm{AN}}$, in a concentration-dependent manner. The latter could be due to higher 
573 contents of polyphenols in the DOC of A. glutinosa than that of A. negundo, respectively 49 574 and $23 \mathrm{mg} \mathrm{PAE} / \mathrm{g}$ DM and, in addition, tannins (7.5 mg PAE/g DM) that were lacking in the 575 DOC of $A$. negundo. It has been found that tannins exhibit strong antioxidant properties in 576 comparison to low molecular weight phenolic compounds. The presence of catechol or galloyl groups in tannin structure are essential to complex formation with transition metals (Andjelković et al., 2006) including copper (Brown and Kelly, 2007; Miller et al, 1996). Phenolic compounds with additional hydroxy groups on aromatic ring bind $\mathrm{Cu}^{2+}$ more efficiently (Brown and Kelly, 2007). The lack of tannins and low polyphenol content, and thus weak $\mathrm{Cu}$ binding ability in $A$. negundo LLE may explain, at least in part, negligible impact of $A$. negundo-derived DOM on the moderation of $\mathrm{Cu}$-induced MDA levels. However, it is also known that phenolics can display prooxidant activities in the presence of metal ions in plants (Decker, 1997; Azam et al., 2004).

In the second response phase, $\mathrm{Cu}$ and its combination with A. glutinosa extracts induced a continuous increase of MDA concentration up to the end of 48-h exposure. This could be related to inactivation of APX, despite that the CAT and POD activity remained above the control level. It is known that inhibition of APX results in an increased level of $\mathrm{H}_{2} \mathrm{O}_{2}$ that contributes to defence gene activation and acts as a substrate for POD involved in defence responses such as lignification and crosslinking of cell wall proteins (Bradley et al., 1992). DOC of A. glutinosa is characterized by higher contents of polyphenols and tannins that are known to support the primary detoxification system (Yamasaki et al., 1997). Our results also showed that $A$. glutinosa leaf extract stimulated POD when it acted individually. In the $\mathrm{Cu}+\mathrm{DOC}_{\mathrm{AG}}$ treatments, exogenous polyphenols and tannins and continuous increase of POD activity, exceeding that of $\mathrm{Cu}$-induced at the end of the 48-h period, suggests that L. minor avoids $\mathrm{H}_{2} \mathrm{O}_{2}$ overproduction through a phenolic-dependent resistance mechanism. This possibility is further supported by the observation that MDA content was diminished by the $\mathrm{DOC}_{\mathrm{AG}}$ in a concentration-dependent manner, which was also true for the first response phase.

Combined treatments of $\mathrm{Cu}$ and $A$. negundo extracts, within initial $3 \mathrm{~h}$, induced different responses of certain oxidative stress enzymes in relation to those of $\mathrm{Cu}$ and A. glutinosa extracts. Contrary to the case of A. glutinosa, when CAT enzyme activity decreased monotonically toward controls (the tendency observed up to $6 \mathrm{~h}$ ), a rapid decrease of CAT activity to control level at $1.5 \mathrm{~h}$ indicated that the ability to scavenge $\mathrm{H}_{2} \mathrm{O}_{2}$ in plants was weakened. Indeed, A. negundo extract (100 mg DOC/L) even acting individually induces fast inactivation of CAT. During 3-6 h period, the relatively higher activity of POD in the relation of CAT, APX and GR activities in the treatments of Cu and A. negundo extracts indicated that actual level of lipid peroxidation could be mainly associated with the POD scavenging of $\mathrm{H}_{2} \mathrm{O}_{2}$. Inactivation of both CAT and the AsA-GSH

611 Overall, within three hours of exposure, the treatments of $\mathrm{Cu}$ in combination with DOC 612 from either A. negundo or A. glutinosa extract yielded lower MDA levels than in the 
613 treatment of $\mathrm{Cu}$, and this was supported by various responses of ROS enzymes. However, 614 after six hours of exposure, plants were unable to cope with $\mathrm{H}_{2} \mathrm{O}_{2}$ excess in the treatments 615 of $\mathrm{Cu}+\mathrm{DOC}_{\mathrm{AN}}$ when lipid peroxidation augmented up to the level observed in $\mathrm{Cu}$-treatment, 616 in contrast to $\mathrm{Cu}+\mathrm{DOC}_{\mathrm{AG}}$ when lipid peroxidation was lower (Fig. 4). This distinction 617 between the influences of various leaf species extracts at the background of $\mathrm{Cu}$ action could 618 be caused by the differences in contents of polyphenolic compounds (see above). higher activities of APX and GR. This finding indicates that consumption of $\mathrm{H}_{2} \mathrm{O}_{2}$ can be associated not only with a POD (see below), but with the enzymatic activities in the AsAGSH cycle, as well. Alteration of these enzymes was led by the inactivation of CAT. The first reason for the latter could be an excess level of AsA in the presence of $\mathrm{Cu}$. Davison et al. (1986) have shown that AsA alone is not very damaging and that AsA's inhibitory action can be released by $\mathrm{O}_{2}, \mathrm{H}_{2} \mathrm{O}_{2}$ or $\mathrm{Cu}^{2+}$, i.e. when AsA is oxidized to semidehydroascorbate (or ascorbyl radical). Ascorbate toxicity depends on the presence of copper (or iron) and oxygen, but oxygen is not required in the presence of $\mathrm{H}_{2} \mathrm{O}_{2}$ (Samuni et al., 1983). Another reason for progressive inactivation of CAT observed in our study could be the presence of phenolic compounds in leaf litter extracts. Although the quantity and composition of the extracts differed, the effect on CAT activity decrease was evident in $100 \mathrm{mg} / \mathrm{L}$ DOC of either extract, especially at the end of 48-h exposure. The similar inhibitive action of certain phenolic compounds on CAT within 24-h exposure has been found for thermophilic fungi (Yüzügüllü et al., 2011).

POD activity did not differ between the treatments of $\mathrm{Cu}$ and either $\mathrm{Cu}+\mathrm{DOC}_{\mathrm{AN}}$ or $\mathrm{Cu}+\mathrm{DOC}_{\mathrm{AG}}$ at $24^{\text {th }}$ hour of exposure. However, the extract type probably determined the opposing POD response at $48^{\text {th }}$ hour of exposure. At this time point, the highest POD activity (exceeding that of the $\mathrm{Cu}$-induced) was observed in the case of $\mathrm{Cu}+\mathrm{DOC}_{\mathrm{AG}}$. The lack of the differences in MDA levels in the second phase of $L$. minor response to $\mathrm{Cu}$ or its combinations with $\mathrm{DOC}_{\mathrm{AN}}$ suggests that, under the influence of $A$. negundo extracts, CAT, POD and AsA-GSH cycle enzymes were unable to minimize the oxidative damage induced by $\mathrm{Cu}$. This is the opposite to the action of A. glutinosa extracts.

Invasive plant species tend to migrate from their native habitats under favourable climatic conditions; therefore, trophic and other relationships in ecosystems are changing. It has been suggested that black alder Alnus glutinosa, native species in Lithuania, and boxelder maple Acer negundo, invasive species in Lithuania, impact the same aquatic organisms in different ways Krevš et al., 2013; Manusadžianas et al., 2014). In this context, we revealed the potential of diverse species DOM to modify Cu toxicity effects on Lemna minor. Both types of leaf litter extracts protected $L$. minor from deleterious effects of lipid peroxidation products during the first response phase (up to $6 \mathrm{~h}$ ) when plants activated stress-coping mechanisms. Throughout the second response phase (6-48 h), cellular defence mechanisms were impaired and the vitality of L. minor steadily decreased. Overall, the analyses of $\mathrm{Cu}$ accumulation in L. minor and binding on DOM, and the dynamics of MDA 
653 content that represents integrative biochemical response, suggest that the reason of 654 beneficial action of $A$. glutinosa extracts compared to that of $A$. negundo is based on the 655 higher contents of polyphenols and tannins.

\section{Conclusions}

657

658

659

660

661

662

663

664

665

666

667

668

669

670

671

672

673

674

675

676

677

678

679

680

681

682

683

684

685

686

687

688

689

690

691

We revealed that leaf litter extracts of black alder Alnus glutinosa, native species in Lithuania, and boxelder maple Acer negundo, invasive species in Lithuania have various potential to modify $\mathrm{Cu}$ toxicity effects on Lemna minor. Analyses of duckweed responses, dynamics of $\mathrm{Cu}$ accumulation in the plant and its binding on the DOM in media allowed to conclude that both types of leaf litter extracts protected L. minor from deleterious effects of lipid peroxidation products during the first response phase within $6 \mathrm{~h}$, however, cellular defence mechanisms were impaired during the prolonged exposure within $6-48 \mathrm{~h}$. The differences in antioxidant enzyme activity profiles ascertained in L. minor treated by mixtures of $\mathrm{Cu}$ and various leaf extracts over two days were considered to condition dissimilar effects on the development of plant fronds and roots observed after seven days. The complex data obtained in the current study could be useful for modelling of aquatic ecosystem responses to the changing environment.

\section{Acknowledgements}

We thank Dr Rimantas Vitkus for discussing data statistical analysis.

\section{References}

Adam N, Leroux F, Knapen D, Bals S, Blust R. 2014. The uptake of ZnO and CuO nanoparticles in the water-flea Daphnia magna under acute exposure scenarios. Environmental Pollution 194:130-137 DOI 10.1016/i.envpol.2014.06.037.

Aebi H. 1984. Oxygen radicals in biological systems. Methods in Enzymology 105:121-126 DOI 10.1016/S0076-6879(84)05016-3.

Alscher RG, Donahue JL, Cramer CL. 1997. Reactive oxygen species and antioxidants: relationships in green cells. Physiologia Plantarum 100:224-233 DOI 10.1111/j.1399-3054.1997.tb04778.x.

Amorim ELC, Nascimento JE, Monteiro JM, Sobrinho TJS, Araújo TAS, Albuquerque UP. 2008. A simple and accurate procedure for the determination of tannin and flavonoid levels and some applications in ethnobotany and ethnopharmacology. Functional Ecosystems and Communities 2:88-94.

Andjelković M, Van Camp J, De Meulenaer B, Depaemelaere G, Socaciu C, Verloo M, Verhe R. 2006. Iron-chelation properties of phenolic acids bearing catechol and galloyl groups. Food Chemistry 98:23-31 D0I 10.1016/j.foodchem.2005.05.044.

Asada K, Takahashi M. 1987. Production and scavenging of active oxygen in photosynthesis. In: Kyle DJ, Osmond CB, Arntzen CJ, eds. Photoinhibition (Topics in Photosynthesis). Amsterdam: Elsevier, 227-287. 
692

693

694

695

696

697

698

699

700

701

702

703

704

705

706

707

708

709

710

711

712

713

714

715

716

717

718

719

720

721

722

723

724

725

726

727

728

729

730

731

732

733

734

735

736

737

Atanassova M, Georgieva S, Ivancheva K. 2011. Total phenolic and total flavonoid contents, antioxidant capacity and biological contaminants in medicinal herbs. Journal of the University of Chemical Technology and Metallurgy 46:81-88.

Azam , Hadi N, Khan NU, Hadi SM. Prooxidant property of green tea polyphenols epicatechin and epigallocatechin-3-gallate: implications for anticancer properties. Toxicoogy in vitro 18:555-561 DOI 10.1016/j.tiv.2003.12.012.

Babu TS, Akhtar TA, Lampi MA, Tripuranthakam S, Dixon DG, Greenberg BM. 2003. Similar stress responses are elicited by copper and ultraviolet radiation in the aquatic plant Lemna gibba: implication of reactive oxygen species as common signals. Plant and Cell Physiology 44:1320-1329 DOI 10.1093/pcp/pcg160.

Bayliak M, Semchyshyn H, Lushchak V. 2006. Effect of hydrogen peroxide on antioxidant enzyme activities in Saccharomyces cerevisiae is strain specific. Biochemistry 71:10131020 DOI 10.1134/S0006297906090100.

Blodau C, Basiliko N, Moore TR. 2004. Carbon turnover in peatland mesocosms exposed to different water table levels. Biogeochemistry 67:331-351

DOI 10.1023/B:BIOG.0000015788.30164.e2.

Bradford MM. 1976. A rapid and sensitive method for the quantitation of microgram quantities of protein utilizing the principle of protein-dye binding. Analytical Biochemistry 72:248-254 DOI 10.1016/0003-2697(76)90527-3.

Bradley DJ, Kjellbom P, Lamb CJ. 1992. Elicitor- and wound-induced oxidative crosslinking of a proline-rich plant cell wall protein: a novel, rapid defense response. Cell 70:21-30 DOI 10.1016/0092-8674(92)90530-P.

Brown JE, Kelly MF. 2007. Inhibition of lipid peroxidation by anthocyanins, anthocyanidins and their phenolic degradation products. European Journal of Lipid Science and Technology 109:66-71 DOI 10.1002/ejlt.200600166.

Casas JJ, Larrañaga A, Menéndez M, Pozo J, Basaguren A, Martínez A, Pérez J, González JM, Mollá S, Casado C, Descals E, Roblas N, López-González JA, Luis Valenzuela J. 2013. Leaf litter decomposition of native and introduced tree species of contrasting quality in headwater streams: how does the regional setting matter? Science of the Total Environment 458-460:197-208 DOI 10.1016/j.scitotenv.2013.04.004.

Chen LM, Lin CC, Kao CH. 2000. Copper toxicity in rice seedlings: changes in antioxidative enzyme activities, $\mathrm{H}_{2} \mathrm{O}_{2}$ level, and cell wall peroxidase activity in roots. Botanical Bulletin of the Academia Sinica 41:99-103.

Cuss CW, Guéguen C. 2012. Impacts of microbial activity on the optical and copperbinding properties of leaf-litter leachate. Frontiers in Microbiology 3:1-10 DOI 10.3389/fmicb.2012.00166.

Davison AJ, Kettle AJ, Fatur DJ. 1986. Mechanism of the inhibition of catalase by ascorbate. The Journal of Biological Chemistry 261:1193-1200.

De Vos CH, Vonk MJ, Vooijs R, Schat H. 1992. Glutathione depletion due to copperinduced phytochelatin synthesis causes oxidative stress in Silene cucubalus. Plant Physiology 98:853-858 D0I 10.1104/pp.98.3.853.

De Vos CHR, Schat H, De Waal MAM, Vooijs R, Ernst WHO. 1991. Increased resistance to copper-induced damage of the root cell plasmalemma in copper tolerant Silene cucubalus. Plant Physiology 82:523-528 DOI 10.1111/j.1399-3054.1991.tb02942.x.

Decker EA. 1997. Phenolics: prooxidants or antioxidants? Nutrition Reviews 55:396-398. Drost W, Matzke M, Backhaus T. 2007. Heavy metal toxicity to Lemna minor: studies on

Peer) reviewing PDF | (2019:12:44535:1:1:CHECK 8 May 2020) 
738

the time dependence of growth inhibition and the recovery after exposure. Chemosphere 67:36-43 DOI 10.1016/j.chemosphere.2006.10.018.

Earl JE, Cohagen KE, Semlitsch RD. 2012. Effects of leachate from tree leaves and grass litter on tadpoles. Environmental Toxicology and Chemistry 31:1511-1517 DOI 10.1002/etc.1829.

Environment Canada. 2007. Biological test method. Test for measuring the inhibition of growth using the freshwater macrophyte, Lemna minor. Report EPS 1/RM/37 DOI 10.1017/CB09781107415324.004.

Forni C, Braglia R, Harren FJM, Cristescu SM. 2012. Stress responses of duckweed (Lemna minor L.) and water velvet (Azolla filiculoides Lam.) to anionic surfactant sodium-dodecyl-sulphate (SDS). Aquatic Toxicology 110-111:107-113 DOI 10.1016/j.aquatox.2011.12.017.

Foyer CH, Halliwell B. 1976. The presence of glutathione and glutathione reductase in chloroplasts: a proposed role in ascorbic acid metabolism. Planta 133:21-25 DOI 10.1007/BF00386001.

Foyer CH, Lopez-Delgado H, Dat JF, Scott IM. 1997. Hydrogen peroxide- and glutathioneassociated mechanisms of acclimatory stress tolerance and signalling. Physiologia Plantarum 100:241-254 DOI 10.1034/j.1399-3054.1997.1000205.x.

González-Guerrero M, Escudero V, Saéz Á, Tejada-Jiménez M. 2016. Transition metal transport in plants and associated endosymbionts: arbuscular mycorrhizal fungi and rhizobia. Frontiers in Plant Science 7:1088 DOI 10.3389/fpls.2016.01088.

Gopalapillai Y, Vigneault B, Hale BA. 2014. Root length of aquatic plant, Lemna minor L., as an optimal toxicity endpoint for biomonitoring of mining effluents. Integrated Environmental Assessment and Management 10:493-497 DOI 10.1002/ieam.1558.

Gudžinskas Z. 1998. Conspectus of alien plant species of Lithuania. 8. Aceraceae, Balsaminaceae, Elaeagnaceae, Geraniaceae, Hippocastanaceae, Linaceae, Lythraceae, Onagraceae, Oxalidaceae, Rutaceae, and Vitaceae. Botanica Lithuanica 4:363-377.

Gupta H, Cuypers A, Vangronsveld J, Clijsters H. 1999. Copper affects the enzymes of the ascorbate-glutathione cycle and its related metabolites in the roots of Phaseolus vulgaris. Physiologia Plantarum 106:262-267 DOI 10.1034/j.13993054.1999.106302.x.

Halliwell B, Gutteridge JMC. 1984. Oxygen toxicity, oxygen radicals, transition metals and disease. Biochemical Journal 219:1-14 DOI 10.1016/j.siny.2010.04.003.

Heath RL, Packer L. 1968. Photoperoxidation in isolated chloroplasts. Archives of Biochemistry and Biophysics 125:189-198 DOI 10.1016/0003-9861(68)90654-1.

Heineke D, Riens B, Grosse H, Hoferichter P, Peter U, Flugge U-I, Heldt HW. 1991. Redox transfer across the inner chloroplast envelope membrane. Plant Physiology 95:1131-1137 DOI 10.1104/pp.95.4.1131.

Hildebrandt DF, Rodriguez JG, Brown GC, Luu KT, Volden CS. 1986. Peroxidative responses of leaves in 2 soybean genotypes injured by 2-spotted spider-mites (Acari, Tetranychidae). Journal of Economic Entomology 79:1459-1465.

Hou W, Chen X, Song G, Wang Q, Chang CC. 2007. Effects of copper and cadmium on heavy metal polluted waterbody restoration by duckweed (Lemna minor). Plant Physiology and Biochemistry 45:62-69 DOI 10.1016/i.plaphy.2006.12.005.

Huh JH and Ahn JW. 2017. A perspective of chemical treatment for cyanobacteria control toward sustainable freshwater development. Environmental Engineering Research 
22:1-11. DOI 10.4491/eer.2016.155.

Jana S, Choudhuri MA. 1981. Glycolate metabolism of three submerged aquatic angiosperms during aging. Aquatic Botany 12:234-354.

Kanoun-Boulé M, Vicente JAF, Nabais C, Prasad MNV, Freitas H. 2009. Ecophysiological tolerance of duckweeds exposed to copper. Aquatic Toxicology 91:1-9

DOI 10.1016/j.aquatox.2008.09.009.

Kim SD, Ma H, Allen HE, Cha DK. 1999. Influence of dissolved organic matter on the toxicity of copper to Ceriodaphnia dubia: effect of complexation kinetics. Environmental Toxicology and Chemistry 18:2433-2437.

Khellaf N, Zerdaoui M. 2009. Phytoaccumulation of zinc by the aquatic plant, Lemna gibba L. Bioresource Technology 100:6137-6140 DOI 10.1016/j.biortech.2009.06.043.

Koukal B, Guéguen C, Pardos M, Dominik J. 2003. Influence of humic substances on the toxic effects of cadmium and zinc to the green alga Pseudokirchneriella subcapitata. Chemosphere 53:953-961 DOI 10.1016/S0045-6535(03)00720-3.

Krevš A, Darginavičienė J, Gylytė B, Grigutytė R, Jurkonienė S, Karitonas R, Kučinskienė A, Pakalnis R, Sadauskas K, Vitkus R, Manusadžianas L. 2013. Ecotoxicological effects evoked in hydrophytes by leachates of invasive Acer negundo and autochthonous Alnus glutinosa fallen off leaves during their microbial decomposition. Environmental Pollution 173:75-84 DOI 10.1016/j.envpol.2012.09.016.

Lachman J, Miholová D, Pivec V, Jírů K, Janovská D. 2011. Content of phenolic antioxidants and selenium in grainof einkorn (Triticum monococcum), emmer (Triticum dicoccum) and spring wheat (Triticum aestivum) varieties. Plant, Soil and Environment 57:235-243 DOI 10.17221/13/2011-PSE.

Li T, Xiong Z. 2004. A novel response of wild-type duckweed (Lemna paucicostata Hegelm.) to heavy metals. Environmental Toxicology 19:95-102 DOI 10.1002/tox.20000.

Lichtenthaler HK. 1996. Vegetation stress: an introduction to the stress concept in plants. Plant Physiology 148:4-14 DOI 10.1016/S0176-1617(96)80287-2.

Lin YM, Liu JW, Xiang P, Lin P, Ye GF, Da Sternberg LSL. 2006. Tannin dynamics of propagules and leaves of Kandelia candel and Bruguiera gymnorrhiza in the Jiulong River Estuary, Fujian, China. Biogeochemistry 78:343-359 DOI 10.1007/s10533-0054427-5.

Lin YM, Liu XW, Zhang H, Fan HQ, Lin GH. 2010. Nutrient conservation strategies of a mangrove species Rhizophora stylosa under nutrient limitation. Plant Soil 326:469479 DOI 10.1007/s11104-009-0026-X.

Madhusudhan KN, Srikanta BM, Shylaja MD, Prakash HS, Shetty HS. 2009. Changes in antioxidant enzymes, hydrogen peroxide, salicylic acid and oxidative stress in compatible and incompatible host-tobamovirus interaction. Journal of Plant Interactions 4:157-166 DOI 10.1080/17429140802419516.

Maksymiec W. 1997. Effects of copper on cellular processes in higher plants. Photosynthetica 34:321-342.

Manceau A, Matynia A. 2010. The nature of $\mathrm{Cu}$ bonding to natural organic matter. Geochimica et Cosmochimica Acta 74:2556-2580 DOI 10.1016/j.gca.2010.01.027.

Mannervik B. 1999. Measurement of glutathione reductase. In: Maines MD, Costa LG, Hodgson E, Reed DJ, Sipes IG, eds. Current Protocols in Toxicology. Hoboken, NJ: John 
830

831

832

833

834

835

836

837

838

839

840

841

842

843

844

845

846

847

848

849

850

851

852

853

854

855

856

857

858

859

860

861

862

863

864

865

866

867

868

869

870

871

872

873

874

875

Wiley \& Sons Inc. 2:7.2.1-7.2.4 DOI 10.1002/0471140856.tx0702s00.

Manusadžianas L, Darginavičienė J, Gylytė B, Jurkonienė S, Krevš A, Kučinskienė A, Mačkinaitė R, Pakalnis R, Sadauskas K, Sendžikaitė J, Vitkus R. 2014. Ecotoxicity effects triggered in aquatic organisms by invasive Acer negundo and native Alnus glutinosa leaf leachates obtained in the process of aerobic decomposition. Science of the Total Environment 496:35-44 DOI 10.1016/j.scitotenv.2014.07.005.

Manusadžianas L, Gylytė B, Grigutytė R, Karitonas R, Sadauskas K, Vitkus R, Šiliauskas L. 2017. Accumulation of copper in the cell compartments of charophyte Nitellopsis obtusa after its exposure to copper oxide nanoparticle suspension.

Environmental Science and Pollution Research 24:27653-27661 DOI 10.1007/s11356-016-8023-0.

Martins D, English AM. 2014. Redox biology catalase activity is stimulated by $\mathrm{H}_{2} \mathrm{O}_{2}$ in rich culture medium and is required for $\mathrm{H}_{2} \mathrm{O}_{2}$ resistance and adaptation in yeast. Redox Biology 2:308-313 DOI 10.1016/i.redox.2013.12.019.

Marx G, Heumann KG. 1999. Mass spectrometric investigations of the kinetic stability of chromium and copper complexes with humic substances by isotope-labelling experiments. Fresenius Journal of Analytical Chemistry 364:489-494.

Miller NJ, Castelluccio C, Tijburg L, Rice-Evans C. 1996. The antioxidant properties of theaflavins and their gallate esters - radical scavengers or metal chelators? FEBS Letters 392:40-44 DOI 10.1016/0014-5793(96)00780-6.

Miyake C, Asada K. 1996. Inactivation mechanism of ascorbate peroxidase at low concentrations of ascorbate; Hydrogen peroxide decomposes compound I of ascorbate peroxidase. Plant and Cell Physiology 37:423-430

DOI 10.1093/oxfordjournals.pcp.a028963.

Nakano Y, Asada K. 1981. Hydrogen-peroxide is scavenged by ascorbate-specific peroxidase in spinach chloroplasts. Plant and Cell Physiology 22:867-880.

Naumann B, Eberius M, Appenroth KJ. 2007. Growth rate based dose-response relationships and EC-values of ten heavy metals using the duckweed growth inhibition test (ISO 20079) with Lemna minor L. clone St. Journal of Plant Physiology 164:16561664 DOI 10.1016/j.jplph.2006.10.011.

Nimptsch J, Pflugmacher S. 2008. Decomposing leaf litter: the effect of allochthonous degradation products on the antioxidant fitness and photosynthesis of Vesicularia dubyana. Ecotoxicology and Environmental Safety 69:541-545

DOI 10.1016/j.ecoenv.2007.09.003.

Palmgren MG, Nissen P. 2011. P-type ATPases. Annual Review of Biophysics 40:243-266 DOI 10.1146/annurev.biophys.093008.131331.

Panagos P, Ballabio C, Lugato E, Jones A, Borrelli P, Scarpa S, Orgiazzi A, Montanarella L. 2018. Potential sources of anthropogenic copper inputs to European agricultural soils. Sustainability 10:2380 DOI 10.3390/su10072380.

Prasad M, Malec P, Waloszek A, Bojko M, Strzałka K. 2001. Physiological responses of Lemna trisulca L.(duckweed) to cadmium and copper bioaccumulation. Plant Science 161:881-889.

Prieditis N. 1997. Alnus glutinosa - dominated wetland forests of the Baltic Region: community structure, syntaxonomy and conservation. Plant Ecology 129:49-94.

Radić, S, Pevalek-Kozlina B. 2010. Effects of osmotic stress on antioxidative system of duckweed (Lemna minor L). Periodicum Biologorum 112:293-299.

Peer) reviewing PDF | (2019:12:44535:1:1:CHECK 8 May 2020) 
876

877

878

879

880

881

882

883

884

885

886

887

888

889

890

891

892

893

894

895

896

897

898

899

900

901

902

903

904

905

906

907

908

909

910

911

912

913

914

915

916

917

918

919

920

921

Razinger J, Dermastia M, Drinovec L, Drobne D, Zrimec A, Koce JD. 2007. Antioxidative responses of duckweed (Lemna minor L.) to short-term copper exposure. Environmental Science and Pollution Research International 14:194-201 DOI 10.1065/espr2006.11.364.

Samuni A, Aronovitch J, Godinger D, Chevion M, Czapski G. 1983. On the cytotoxicity of vitamin $\mathrm{C}$ and metal ions: a site-specific Fenton mechanism. European Journal of Biochemistry 137:119-124 DOI 10.1111/j.1432-1033.1983.tb07804.x.

Schützendübel A, Polle A. 2002. Plant responses to abiotic stresses: heavy metal-induced oxidative stress and protection by mycorrhization. Journal of Experimental Botany 53:1351-1365 DOI 10.1016/S0981-9428(02)01411-0.

Sinclair SA, Krämer U. 2012. The zinc homeostasis netork of land plants. Biochimica et Biophysica Acta 1823:1553-1567 DOI 10.1016/j.bbamcr.2012.05.016.

Singleton VL, Orthofer R, Lamuela-Raventós RM. 1998. Analysis of total phenols and other oxidation substrates and antioxidants by means of Folin-Ciocalteu reagent. Methods in Enzymology 299:152-178 DOI 10.1016/S0076-6879(99)99017-1.

Steinberg CEW. 2003. Ecology of humic substances in freshwaters: determinants from geochemistry to ecological niches. Berlin, New York: Springer.

Steinberg CEW, Paul A, Pflugmacher S, Meinelt T, Klöcking R, Wiegand C. 2003. Pure humic substances have the potential to act as xenobiotic chemicals - a review. Fresenius Environmental Bulletin 12:391-401.

Stevenson FJ. 1994. Humus chemistry - genesis, composition, reactions, New York: John Wiley, $2^{\text {nd }}$ ed.

Tank JJL, Rosi-Marshall EJE, Griffiths NA, Entrekin SA, Stephen ML. 2010. A review of allochthonous organic matter dynamics and metabolism in streams. Journal of the North American Benthological Society 29:118-146 DOI 10.1899/08-170.1.

Teisseire H, Couderchet M, Vernet G. 1998. Toxic responses and catalase activity of Lemna minor L. exposed to folpet, copper, and their combination. Ecotoxicology and Environmental Safety 40:194-200 DOI 10.1006/eesa.1998.1682.

Teisseire H, Guy V. 2000. Copper-induced changes in antioxidant enzymes activities in fronds of duckweed (Lemna minor). Plant Science 153:65-72 DOI 10.1016/S0168-9452(99)00257-5.

Thomas G, Stärk HJ, Wellenreuther G, Dickinson BC, Küpper H. 2013. Effects of nanomolar copper on water plants - comparison of biochemical and biophysical mechanisms of deficiency and sublethal toxicity under environmentally relevant conditions. Aquatic Toxicology 140-141:27-36 DOI 10.1016/j.aquatox.2013.05.008.

Upadhyaya A, Sankhla D, Davis TD, Sankhla N, Smith BN. 1985. Effect of paclobutrazol on the activities of some enzymes of activated oxygen metabolism and lipid peroxidation in senescing soybean leaves. Journal of Plant Physiology 121:453-461.

US Environmental Protection Agency. 2012. Ecological effects test guidelines. Aquatic plant toxicity test using Lemna spp. Report OCSPP 850.4400.

Wang H, Shan X, Wen B, Zhang S, Wang Z. 2004. Responses of antioxidative enzymes to accumulation of copper in a copper hyperaccumulator of Commoelina communis. Archives of Environmental Contamination and Toxicology 47:185-192 DOI 10.1007/s00244-004-2222-2.

Wang W. 1990. Literature review on duckweed toxicity testing. Environmental Research 52:7-22 DOI 10.1016/S0013-9351(05)80147-1.

Peer) reviewing PDF | (2019:12:44535:1:1:CHECK 8 May 2020) 
922 Weckx JEJ, Clijsters HMM. 1996. Oxidative damage and defense mechanisms in primary 923 leaves of Phaseolus vulgaris as a result of root assimilation of toxic amounts of copper. Physiologia Plantarum 96:506-512 DOI 10.1034/j.1399-3054.1996.960322.x.

Wetzel RG. 2001. Limnology: lake and river ecosystems. San Diego, California: Academic Press, $3^{\text {rd }}$ ed.

Xia J and Tian Q. 2009. Early stage toxicity of excess copper to photosystem II of Chlorella. pyrenoidosa - OJIP chlorophyll a fluorescence analysis. Journal of Environmental Sciences 21:1569-1574 DOI 10.1016/S1001-0742(08)62457-2.

Xiang C, Oliver DJ. 1998. Glutathione metabolic genes coordinately respond to heavy metals and jasmonic acid in Arabidopsis. Plant Cell 10:1539-50 DOI 10.1105/tpc.10.9.1539.

Xing W, Huang W, Liu G. 2010. Effect of excess iron and copper on physiology of aquatic plant Spirodela polyrrhiza (L.) schleid. Environmental Toxicology 25:103-112 DOI 10.1002/tox.20480.

Yamasaki H, Sakihama Y, Ikehara N. 1997. Flavonoid-peroxidase reaction as a detoxification mechanism of plant cells against $\mathrm{H}_{2} \mathrm{O}_{2}$. Plant Physiology 115:1405-1412 DOI 10.1104/pp.115.4.1405.

Yüzügüllü Y, Ögel ZB, Bölükbaşi UB, Çoruh N, Karakaş G. 2011. Production of a novel bifunctional catalase-phenol oxidase of Scytalidium thermophilum in the presence of phenolic compounds. Turkish Journal of Biology 35:697-704 DOI 10.3906/biy-1009$\underline{105}$.

Zezulka Š, Kummerová $\mathbf{M}$, Babula $\mathbf{P}$, Váňová L. 2013. Lemna minor exposed to fluoranthene: growth, biochemical, physiological and histochemical changes. Aquatic Toxicology 140-141:37-47 DOI 10.1016/j.aquatox.2013.05.011. 


\section{Figure 1}

Frond and root growth of $L$. minor exposed to copper, leaf litter extracts (LLE) of Alnus glutinosa or Acer negundo, and combinations of Cu and LLE

Frond (A) and root (B) growth rates of L.minor in control (C) and exposed for seven days with $100 \mu \mathrm{M} \mathrm{CuSO}_{4}(\mathrm{Cu})$, mixtures of $\mathrm{Cu}$ and A.glutinosa leaf litter extracts (LLE) of 10 and $100 \mathrm{mg} / \mathrm{L} \mathrm{DOC}\left(\mathrm{Cu}+10-\mathrm{DOC}_{\mathrm{AG}}\right.$ and $\left.\mathrm{Cu}+100-\mathrm{DOC}_{\mathrm{AG}}\right)$, mixtures of $\mathrm{Cu}$ and A. negundo LLE of 10 and $100 \mathrm{mg} / \mathrm{L} \mathrm{DOC}\left(\mathrm{Cu}+10-\mathrm{DOC}_{\mathrm{AN}}\right.$ and $\left.\mathrm{Cu}+100-\mathrm{DOC}_{\mathrm{AN}}\right)$ as well as with $100 \mathrm{mg} / \mathrm{L} \mathrm{DOC}$ of A.glutinosa (100-DOC $\mathrm{AG}_{\mathrm{AG}}$ ) and A.negundo (100-DOC $\left.\mathrm{AN}_{\mathrm{N}}\right)$ LLE. Data represent mean $\pm \mathrm{SD}(\mathrm{n}=8)$. Asterisksindicate significant difference from the control, different letters indicate significant difference among the means $(\alpha=0.05)$. 

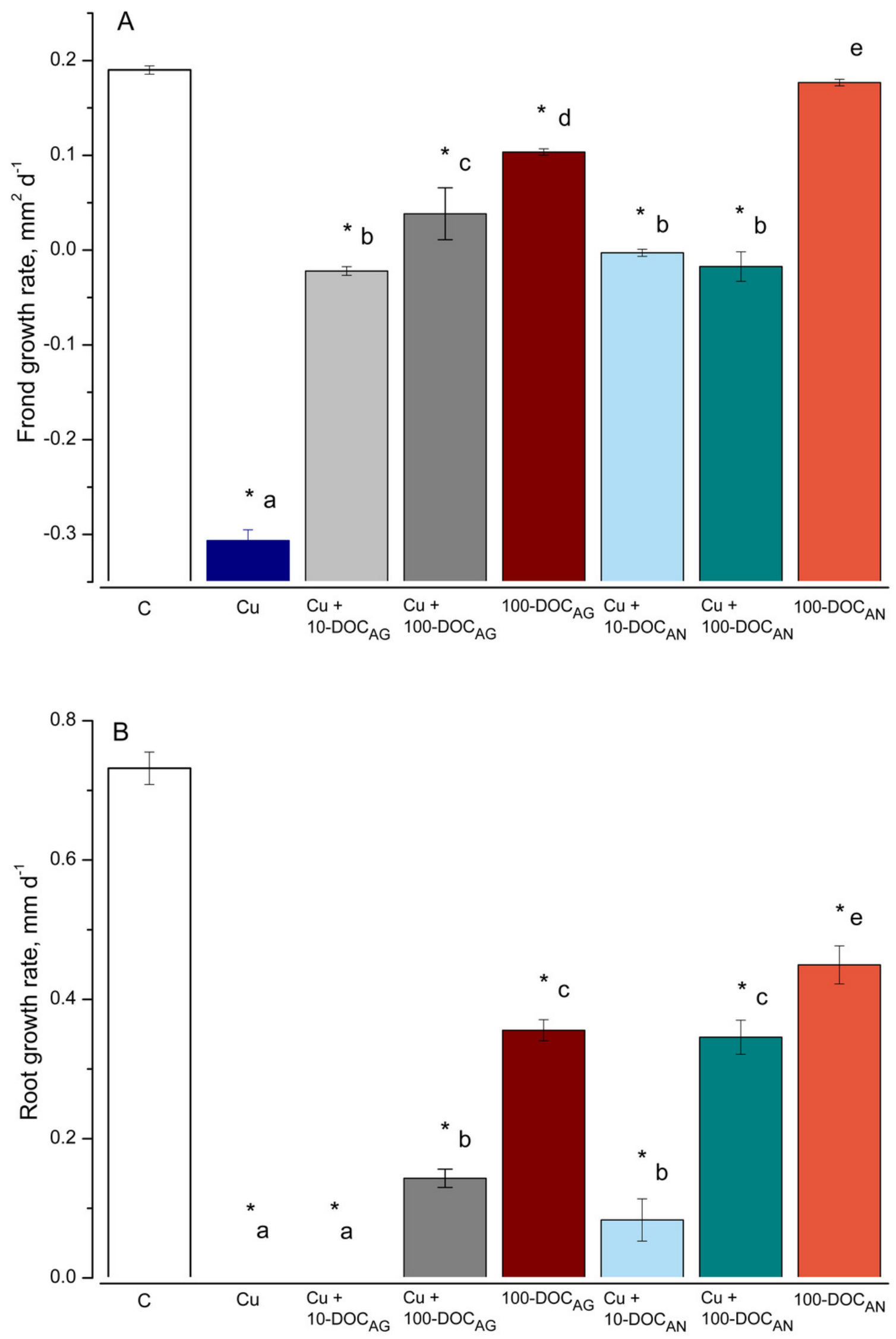
Figure 2

$\mathrm{Cu}$ accumulation in $\mathrm{L}$. minor treated by $\mathrm{Cu}$, and combinations of $\mathrm{Cu}$ and leaf litter extracts from $A$. glutinosa or $A$. negundo

Cu concentration in L. minor treated by $\mathrm{Cu}$ and Cu+DOC of leaf litter extracts ( $\left.\mu \mathrm{g} \mathrm{g}^{-1} \mathrm{FW}\right)$.

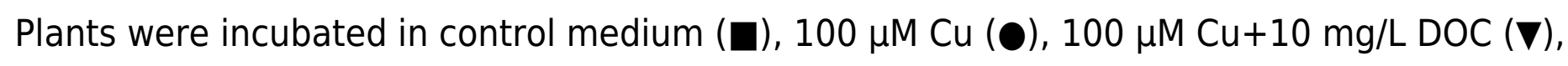
$100 \mu \mathrm{M} \mathrm{Cu}+100 \mathrm{mg} / \mathrm{L} \mathrm{DOC} \mathrm{( \Lambda )} \mathrm{from} \mathrm{A.} \mathrm{glutinosa} \mathrm{or} \mathrm{A.} \mathrm{negundo.} \mathrm{Each} \mathrm{value} \mathrm{represents}$ mean $\pm S D(n=8)$. Asterisks indicate significant difference from the control at $\alpha=0.05$. 

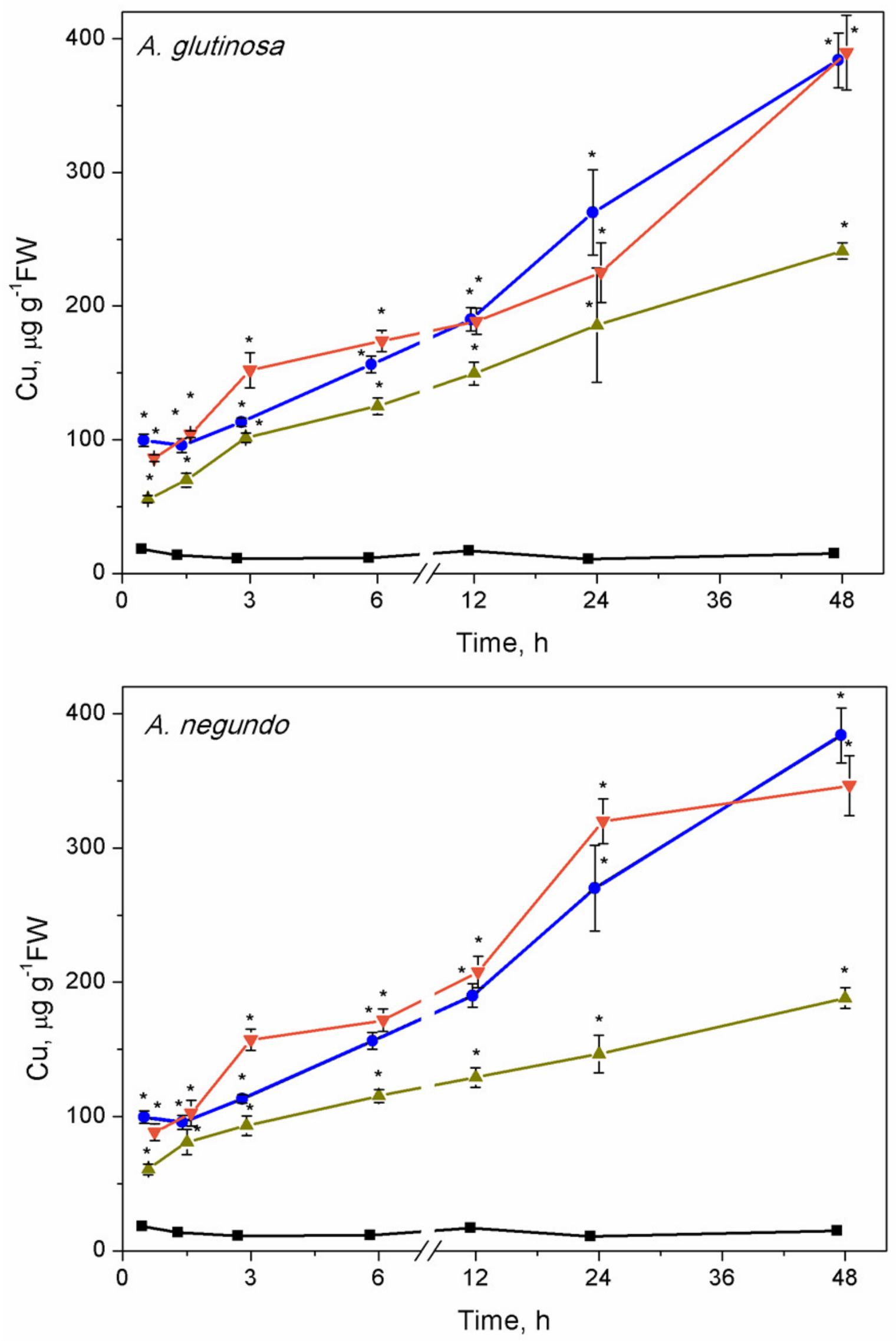


\section{Figure 3}

Concentration of hydrogen peroxide in $\mathrm{L}$. minor treated by $\mathrm{Cu}$, leaf litter extracts and $\mathrm{Cu}$ + leaf litter extracts.

Concentration of $\mathrm{H}_{2} \mathrm{O}_{2}$ in L.minor treated by $\mathrm{Cu}, \mathrm{DOC}$ or combinations of $\mathrm{Cu}$ and DOC of corresponding leaf litter extracts. Plants were incubated in control medium ( $\mathbf{\square}), 100 \mu \mathrm{M} \mathrm{Cu}$

(•), $100 \mathrm{mg} / \mathrm{L} \mathrm{DOC}$ from A. glutinosa or A.negundo (o), and Cu+10 mg/L DOC (v) or Cu + 100 $\mathrm{mg} / \mathrm{L} \mathrm{DOC} \mathrm{( \Lambda ).} \mathrm{Each} \mathrm{value} \mathrm{represents} \mathrm{mean} \pm \mathrm{SD}(\mathrm{n}=8)$. Asterisks indicate significant difference from the control at $\alpha=0.05$. 

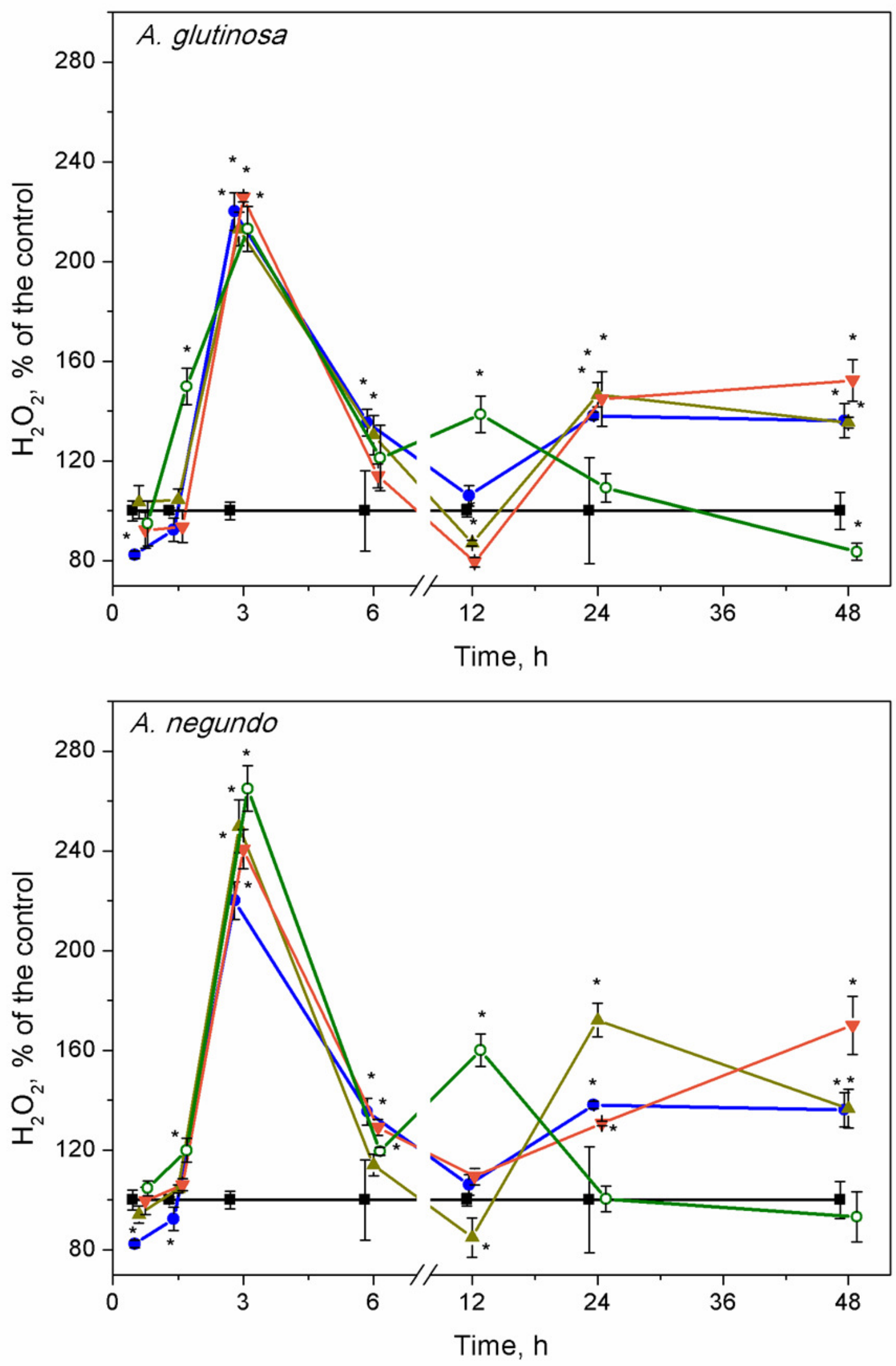


\section{Figure 4}

Lipid peroxidation expressed as MDA concentration in $L$. minor treated by $\mathrm{Cu}$, leaf litter extract of $A$. glutinosa or $A$. negundo, and combinations of $\mathrm{Cu}$ and corresponding extracts

Lipid peroxidation expressed as MDA concentration in L. minor treated by Cu, DOC or combinations of $\mathrm{Cu}$ and $\mathrm{DOC}$ from $A$. glutinosa or $A$. negundo leaf litter extracts. Plants were

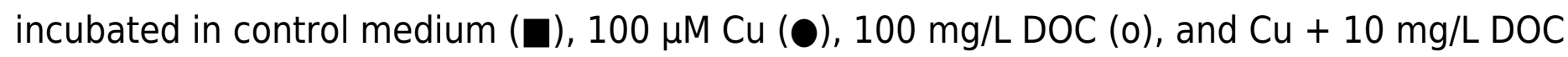
$(\boldsymbol{\nabla})$ or $\mathrm{Cu}+100 \mathrm{mg} / \mathrm{L} \mathrm{DOC} \mathrm{( \Lambda ).} \mathrm{Each} \mathrm{value} \mathrm{represents} \mathrm{mean} \pm \mathrm{SD}(\mathrm{n}=8)$. Asterisks indicate significant difference from the control at $\alpha=0.05$. 

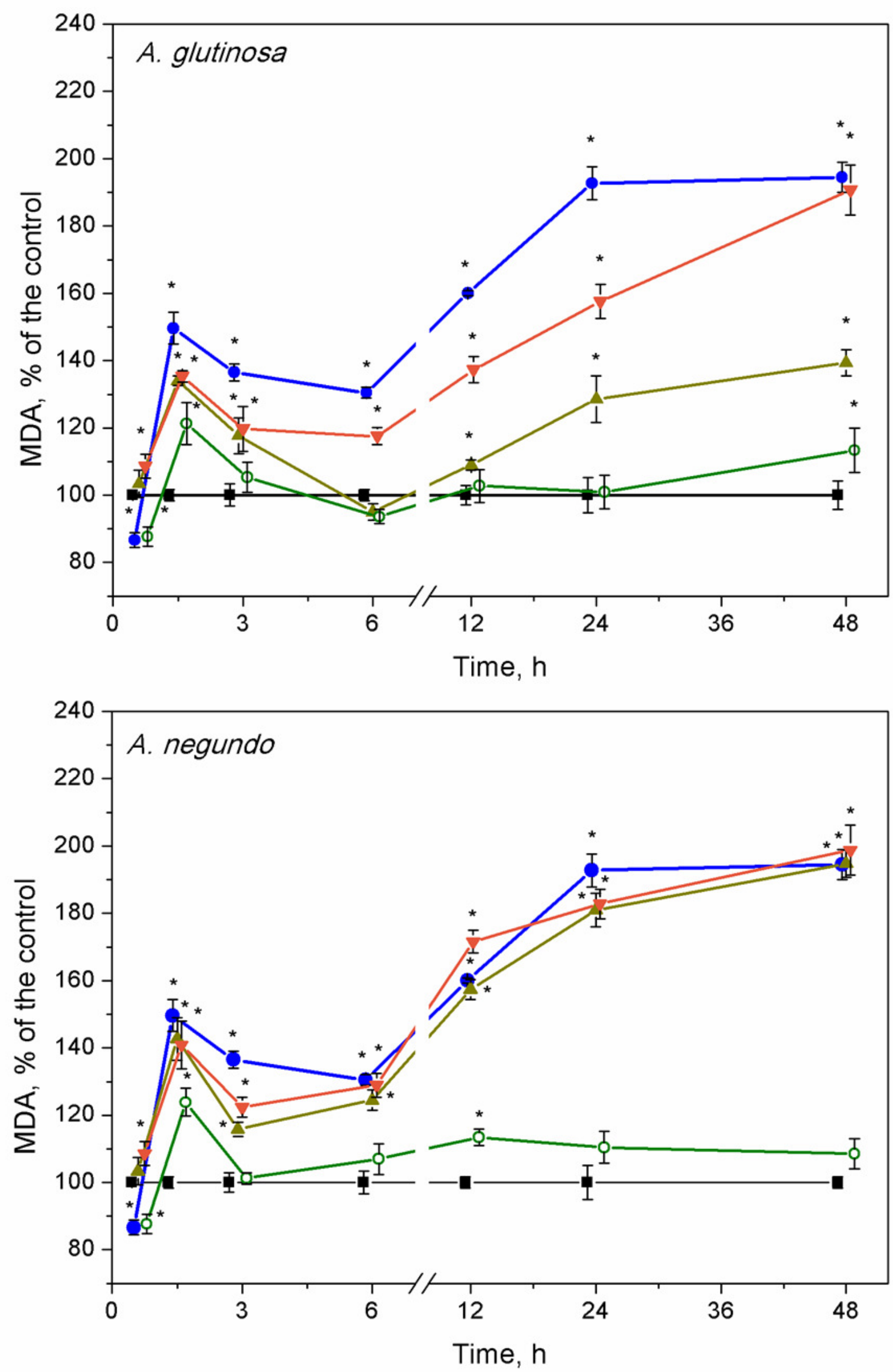


\section{Figure 5}

Oxidative stress enzyme activities in L. minor treated by $\mathrm{Cu}$, leaf litter extract from $A$. glutinosa or $\mathrm{A}$. negundo, and combinations of $\mathrm{Cu}$ and respective extracts

Activities of catalase (CAT), guaiacol peroxidase (POD), ascorbate peroxidase (APX) and glutathione reductase (GR) in L. minor treated by $\mathrm{Cu}, \mathrm{DOC}$ of leaf litter extracts from $A$. glutinosa or $\mathrm{A}$. negundo, and combinations of $\mathrm{Cu}$ and the DOC of respective extract. Plants were incubated in control medium (ם), $100 \mu \mathrm{M} \mathrm{Cu}(\bullet), 100 \mathrm{mg} / \mathrm{L} \mathrm{DOC} \mathrm{(o),} \mathrm{Cu+10} \mathrm{mg/L} \mathrm{DOC}$ $(\boldsymbol{\nabla})$ or $\mathrm{Cu}+100 \mathrm{mg} / \mathrm{L} \mathrm{DOC} \mathrm{( \Lambda ).} \mathrm{Each} \mathrm{value} \mathrm{represents} \mathrm{mean} \pm \mathrm{SD}(\mathrm{n}=8)$. Asterisks indicate significant difference from the control at $\alpha=0.05$. 

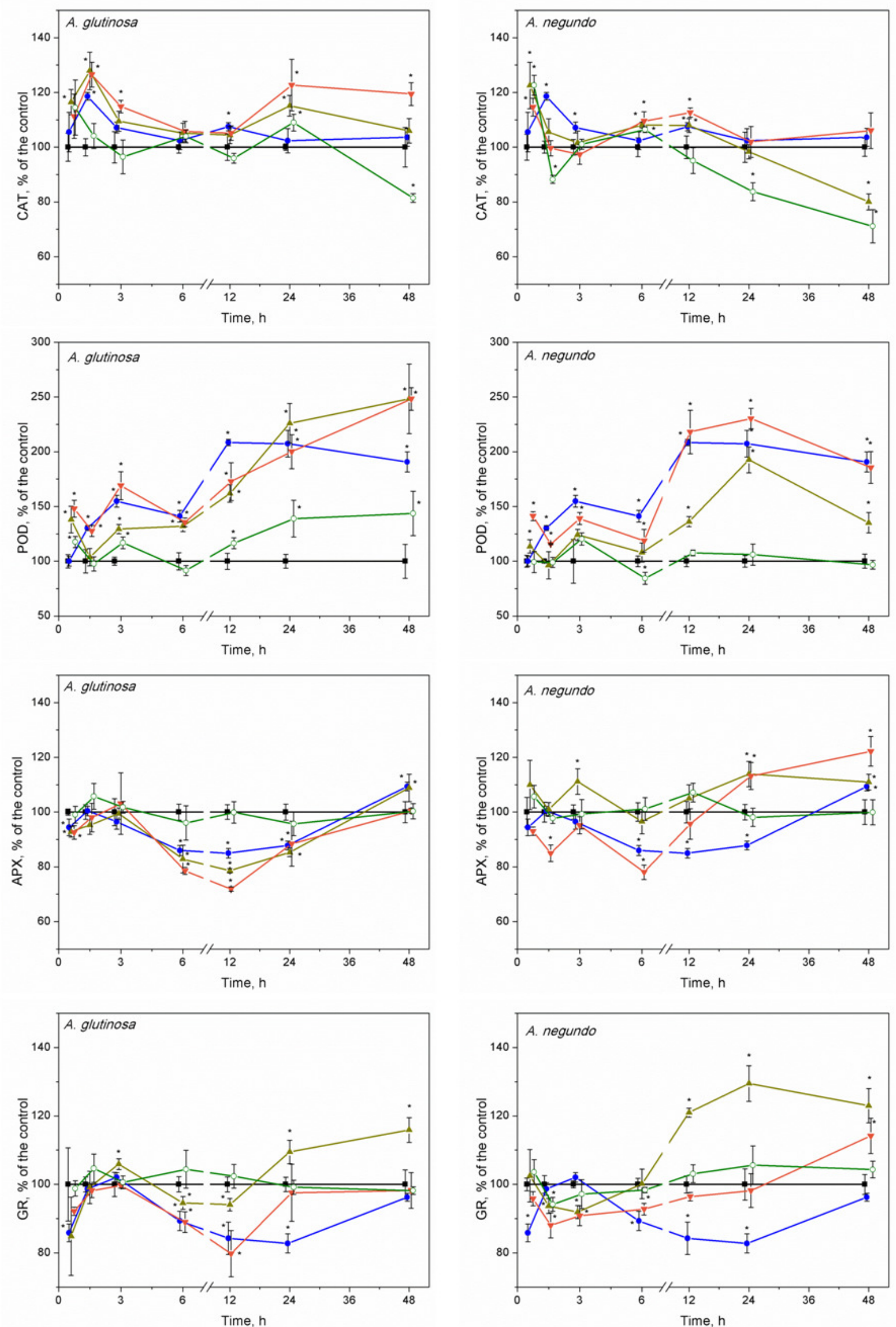